Ankara Üniversitesi Türk Inkılâp Tarihi Enstitüsü Atatïrk Yolu Dergisi

S 27-28. Mayts-Kastm 2001, s. 429-467

\title{
Atatürk Yolu Dergisi Dizini \\ Cilt I-VI, Sayı 1-24
}

\author{
Arş. Gör. Alper BAKACAK*
}

Atatürk Yolu Dergisi'nin ilk yirmidört sayısını kapsayan dizini üç bölümden oluşmaktadır. Buna göre makale künyeleri birinci bölümde, yazar soyadlarına, ikinci bölümde, başlıklarına, üçüncü bölümde konularına göre tasnif edilmeye çalışılmıştır. Bu üç bölümde de dizin alfabetik bir sıra takip edilerek oluşturulmuştur.

\section{YAZAR SOYADINA GÖRE}

Açıkel Erdal: Lozan'da Türkiye İle Amerika Birleşik Devletleri Arasanda Imzalanan 6 Ağustos 1923 Tarihli Antlaşma. VI/21 (1998) 1-31.

Akandere, Osman: II Nisan 1920 (1336) Tarihli Takvim-i Vekâyi'de Kuva-yı Milliye Aleyhinde Yaymlanan Kararlar. VI/24 (1999-2003) 417-467.

Akarslan, Mediha: 1920-1921 Yıllarında Rusya Hariciye Komiserliği Ile Türkiye Büyük Millet Meclisi (T.B.M.M.) Arasında Kurulan İletişim. IV/16 (1995) 467490.

Akarslan, Mediha: Milli Mücadele Döneminde Balıkesir'de Kamuoyunun Olușmast ve Hey'et-i Merkeziye Karar Defteri. V/17 (1996) 1-24.

Akçakayalığlu, Cihat: Dahi Atatürk. II/5 (1990) 167-176.

Akçakayalığlu, Cihat: İstiklâl Harbimiz Üzerine Bazı Dïşünceler. II/8 (1991) 627629.

Akçakayalıoğlu, Cihat: Milli Kültürümüzde Atatürkçiülük ve Bugünümüz. I/3 (1989) 281-284.

Akgün, Seçil: Amerikalı Misyonerlerin Ermeni Meselesindeki Rolü. I/1 (1988) 1-12.

\footnotetext{
* A.Ü. Türk İnkılâp Tarihi Enstitüsü Araştırma Görevlisi.
} 
Akgün, Seçil Karal: Babam Enver Ziya Karal. VI/22 (1998) 165-171.

Akgün, Seçil-Uluğtekin, Murat: Misak-ı Maarif. I/3(1989) 285-349.

Akşun, İnal Zeki: Karizma ve Atatïrk'ün Önderliğindeki Gelişimi. I/2 (1988) 201213.

Albayrak, Mustafa: Atatürk ve Anti-Emperyalizm. V/20 (1997) 347-363.

Albayrak, Mustafa: Atatürkçü Düşünce Sistemi ve Liberalizm. V/18 (1996) 89-121.

Albayrak, Mustafa: Yeni Türk Harflerinin Kabulü Öncesinde Türk Kamuoyunda Bazı Tartışmalar ve Millet Mekteplerinin Açılması (1862-1928). I/4 (1989) 463499.

Algıer, İclâl: Mondrostan Sonra Ermeni Meselesine Kısa Bir Bakış. I/3(1989) 351354.

Arıkan, Zeki: Halkevlerinin Kuruluşu ve Tarihsel İşlevi. VI/23 (1999) 261-281.

Arıkan, Zeki: İşgal Sırasında İzmirde Kurulan Bir Dernek. I/3 (1989) 355-369.

Arıkan, Zeki: Köylü Gazetesi ve İşgal. I/2 (1988) 187-200.

Arıkan, Zeki: Latin Harfler. II/5 (1990) 1-19.

Arıkan, Zeki: Milli Mïcadele'de Balıkesir. VI/24 (1999-2003) 469-474.

Arıkan, Zeki: Muhittin Birgen, Mustafa Kemal Paşa ve Milli Mücadele. V/20 (1997) 365-386.

Arıkan, Zeki: "Teşvik-i Maarif Cemiyeti" İ̧̧ Tüzü̈̆̈̈. II/7 (1991) 403-421.

Ankan, Zeki: Türkiye'nin Çağdaşlaşmasında Tevfik Fikret ve Atatürk. VI/22 (1998) 119-140.

Arıkan, Zeki: Yeni Gün Müsabakası'nda Mustafa Kemal Paşa. III/11 (1993) 243258.

Arslan, Ali: Anadolu Fevkalade Müfettiş-i Umumiliği - IV. Ve V. Damat Ferit Hükümetlerinin Anadolu'daki Yönetimi Büyük Millet Meclisi'nden Geri Alma Teşebbüsü (1920) -. IV/16 (1995) 443-453.

Aslan, Esat: Kurtuluş Savaşında Yunan-Fener Patrikhanesi Birlikteliğine Karşı Örgütlii Bir Yaklaşım Türk Ortodoks Kilisesi. IV/15 (1995) 407-442.

Aşkun, İnal Cem: Atatürk İlkelerinin Kișilik Boyutları ve Eğitim Ortamı. I/4 (1989) 501-515.

Aşkun, İnal Cem: Cumhuriyetimizin Temeli: Atatürkçü Düşünce. V/20 (1997) 387397.

Aşkun, İnal Cem: Söylev'deki Kişiliği ile Atatürk. III/11 (1993) 259-270. 
Aşkun, İnal Cem: Türkiye'de Ekonomik Kamu Düzeni Kavramına Bağlı Örgütsel Yönetimin Atatürkçü Diişünce ve Kişilik Temelinde Konumuna Iliş̧kin Bir Inceleme I. II/7 (1991) 423-442.

Aşkun, İnal Cem: Türkiye'de Ekonomik Kamu Düzeni Kavramlarma Bağlı Örgütsel Yönetimin Atatürkçü Düşïnce ve Kişilik Temelinde Konumuna Illş̧kin Bir Inceleme II. II/8 (1991) 591-626.

Atanur, Ibrahim Ethem: Osmanlı Hükümetleri ve Tehcir Edilen Rum ve Ermenilerin Yeniden İskan Meselesi. IV/14 (1994) 121-139.

Avc1, Cemal: İsmet İnönü'nün Lozan Dönüsü ve Demeçleri (10 Ağustos 1923-23 Ağustos 1923). III/12 (1993) 341-354.

Avcı, Cemal: Milli Mücadele Döneminde Türk-Ermeni ve Gürcü Ilişkileri. IV/13 (1994) 1-10.

Aybars, Ergun: Atatürk ve Devrim'e Bakış. II/7 (1991) 443-453.

Aydın, Mesut: Hamza Grubu. I/3 (1989) 371-394.

Aydın, Mesut: Milli Mücadele Döneminde Anadoluda Giriş ve Çıkışları Kontrol Altında Tutan Kuruluşlar. II/5 (1990) 21-47.

Aydın, Mesut-Dündar, Recep: Milli Mücadele Döneminde İstanbul'dan Anadolu'ya Geçen Subaylar. II/6 (1990) 177-260.

Aydınel, Sıtkı: Gazi Mustafa Kemal'in Samsun Öğretmenleri İle Konuşması (22. IX. 1924). III/9 (1992) 1-8.

Aytepe, Oğuz: Milli Mücadele'de Manda Sorunu ve Mustafa Kemal'in Yaklaşumı. VI/24 (1999-2003) 475-586.

Balcıoğlu, Mustafa: Cumhuriyetin İlk Yıllarında Gençliğin Savaşa Hazırlanması Ile İlgili Iki Belge Iki Görüş. V/20 (1997) 465-473.

Balcıŏ̆lu, Mustafa: Milli Mücadele Sırasında Merkezi Anadolu'da Asayişi Sağlamak İçin Oluşturulan Milis Kuruluşları. II/6 (1990) 261-274.

Baran, Tülay Alim: Milli Teşkilatlar ve İstanbul Hükümetleri. VI/23 (1999) 283298.

Baykal, Hülya: Atatürk'ün Bazı Kuruluşların Hatıra Defterlerine Yazdıkları. I/2 (1988) 181-186.

Baykal, Hülya: Cumhuriyetin Onuncu Yıldönümünde Atatürk'ün Kordiplomatiğe Bir Söylevi. I/3 (1989) 395-397.

Baykal, Hülya: Kurtuluş Savaşı'nda Türk-Fransız Ilişkileri ve Bir Fransız Türk Dostu Albay Mougin. II/7(1991) 455-511.

Bayter, Hacer: Ankara Üniversitesi Türk Inkılap Tarihi Enstitüsü ve Enstitüde Hazırlanan Yüksek Lisans-Doktora Tezleri. VI/23 (1999) 299-319. 
Bilgen, Deniz: Wilson Illkelerine Türk Kamuoyunun Tepkisi ve Bunun Amerikan Basmuna Yansmması. V/18 (1996) 123-130.

Bursalığlu, Ziya: Atatürk ve Sonrast Eğitim. I/4 (1989) 517-521.

Bursalıoğlu, Ziya: Yabancı Gözz̈yle Atatürk. II/6 (1990) 275-280.

Çağlar, Günay: Hüsrev Bey Heyet-i Nasihası. II/5 (1990) 85-96.

Çağlar, Günay: Kuvây-ı İnzibâtiye. IV/15 (1995) 343-365.

Çağlar, Günay: XXIV. Tümen Komutanı Yarbay Mahmud Bey Olayı. III/12 (1993) 355-361.

Çapa, Mesut: Bir Harbiyelinin Milli Mïcadele Antları. IV/14 (1994) 141-166.

Çapa, Mesut: Lozan'da Öngörülen Türk Ahâli Mübadelesinin Uygulanmasında Türkiye Kızılay (Hilâl-i Ahmer) Cemiyeti'nin Katkıları. I/2 (1988) 241-256.

Çapa, Mesut: İstikbal Gazetesine Göre Trabzon'da Mübadele ve İskân. II/8 (1991) 631-641.

Çapa, Mesut: Milli Mücadele Döneminde İstikbal Gazetesi. III/10 (1992) 133-168.

Çapa, Mesut: Milli Mücadele Yıllarında Anadolu'daki Yunan Savaş Esirlerini Ziyaret Eden Uluslararası Illk Kızılhaç Heyeti. II/6 (1990) 281-294.

Çapa, Mesut: Sakarya Savaşından Sonra Imzalanan Türk-Ingiliz Esir Mübadelesi Anlaşmasının Uygulanması ve Belgeler. I/3 (1989) 399-418.

Çapa, Mesut: Yunanistan'dan Gelen Göçmenlerin İskânı. II/5 (1990) 49-84.

Çelik, Birten: Bir Makale ve Dïşündürdükleri. V/17 (1996) 25-32.

Çiçek, Rahmi: Ankara Hükümeti'nin Dünya'ya Açılan Kaptsı İnebolu-Ankara Yolu. $\mathrm{V} / 20399-413$.

Çiçek, Rahmi: Erzurum Vilayet Kongresinde Alman Kararlar ve Etkileri. II/7 (1991) 513-537.

Çiçek, Rahmi: Milli Mücadelede Ermeni-Rum-Yunan İttifakının Anadolu Basımındaki Yankıları. IL/6 (1990) 295-306.

Çiçek, Rahmi: Sakarya Savaşı Öncesi Karadeniz'de Yunan Ablukası ve İnebolu Bombardımam. III/10 (1992) 169-179.

Çiğdemoğlu, Sema: Atatürk ve Yabancı Gözü Ille Bize Bıraktığı Miras. IV/16 (1995) 515-527.

Çufalı, Mustafa: Istiklal Harbi Döneminde Batı Anadolu'da Yunan Zulmü, 1921. VI/21 (1998) 33-48.

Çukurova, Bülent: Büyük Taarruz Günlerinde Ali Kemal ve Siyasi Görüşleri. VI/23 (1999) 357-370. 
Çukurova, Bülent: Milli Mücadele Antları Üzerine Bir Bibliyografya Denemesi. VI/23 (1999) 321-356.

Daver, Bülent: Savaş ve Barı̧̧ Üzerine. III/10 (1992) 181-186.

Doğanay, Rahmi: Çanakkale Zaferinin Türk ve Dïnya Tarihi Açısından Sonuçları. III/12 (1993) 363-371.

Doğanay Rahmi: Kurtuluş Savaşının Diplomatik Bir Cephesi- Inebolu. VI/21 (1998) 49-64.

Doğanay, Rahmi: Rawlinson'un Gözüyle Mütareke Döneminde Doğu Anadolu ve Kafkasya. VI/23 (1999) 371-390.

Ekinci, Necdet: Kurtuluş Savaşı'nda Istanbul ve Anadolu'daki Türk ve Dïşman Gizli Faaliyetleri. IV/14 (1994) 167-184.

Eraslan, Cezmi: Türkiye'de Çok Partili Siyasi Hayatın Kurulmasında Bir Dönüm Noktast: 12 Temmuz (1947) Beyannamesi. VI/22 (1998) 141-157.

Erendil, Muzaffer: Atatürk Çağdaş Eğitimden Yana. I/4 (1989) 523-534.

Erendil, Muzaffer: Atatürk, Medeniyet ve Dünya Kamu Oуи. II/5 (1990) 97-107.

Erendil, Muzaffer: Atatürk: Dünya Barı̧ından Yana Bir Asker. I/2 (1988) 165-179.

Erendil, Muzaffer: Evrensel Nitelikleriyle Atatürk. II/6 (1990) 307-319.

Erendil, Muzaffer: Evrensel Nitelikleriyle Atatürk. III/9 (1992) 9-21.

Erkun, Vecdet: Atatürk Döneminde Tarım Politikası. V/18 (1996) 243-248.

Görgülü, İsmet: Atatïrkçülük ve Hoşgörï̈. V/17 (1996) 33-45.

Görgülü, İsmet: Çanakkale Zaferi ve Atatürk. IV/16 (1995) 491-500.

Gül, Mustafa: Elviye-i Selâse'nin Osmanlı Devleti'ne Iadesi ve Bazı Uygulamalar. IV/15 (1995) 367-380.

Güneş, İhsan: Ali Rıza Paşa Hükûmeti Programı ve Meclis-i Mebusandaki Yankılar. I/1 (1988) 13-27.

Güneş, İhsan: Azmi Milli Yurdu Nizamnamesi. III/12 (1993) 373-382.

Gürbüz, Musa: Paris Barış Konferansı ve Sadri Maksudi'nin Türkiye'yi Savunma Mücadelesine Bir Örnek. V/17 (1996) 47-60.

Huyugüzel, Ö. Faruk: Cumhuriyet Dönemi Türk Edebiyatında Halk Evlerinin Rolï. VI/23 (1999) 391-400.

Hülagü, M. Metin: Muvahhidin Cemiyeti. III/12 (1993) 383-392.

Hülagü, M. Metin: Türk Kurtuluş Savaşı Dönemi Türkiye-Isslam Ülkeleri Münasebetleri. IV/13 (1994) 11-25.

İlter, Erdal: Fransa'nun Suriye 'yi İşgaline Dair Yaymlanmış Bir Risâle. V/17 (1996) 61-81. 
İlter, Erdal: Milli Mücadele'de "Doğu Lejyonu” (D'Orient)'nun Fransız Issâl Bölgesindeki Fonksiyonu. I/3 (1989) 419-436.

Kaplan, Leyla: Cumhuriyetin Ilk Yıllarında Hiukïmetin Milli Ekonomi Oluşturma Girişimlerine Bir Örnek. VI/22 (1998) 159-164.

Karaca, İclâl: 1919 Yılı Osmanlı İmparatorluğu'nda Osmanlılık Fikri Üzerine Değişik Görüşler. II/7(1991) 539-550.

Kasalak, Kadir: Sivas Kongresi Öncesinde "Manda ve Himayenin" Türk Basınında Tartışması ve Komutanlar Arasında Yazışmalar. III/10 (1992) 187-211.

Keleşyılmaz, Vahdet: Atatiirk'ün Bulgar Basınındaki Önemli Bir Polemik Hakkındaki Bilgi ve Görüşleri ve Ulusal Dış Politika Üzerine. V/20 (1997) 415 422 .

Keleşyılmaz, Vahdet: Bir Kuva-yı Milliye Gazetesine Göre Türk Barışı ve Ingiltere. V/19 (1997) 249-264.

Keleşyılmaz, Vahdet: Teşkilat-ı Mahsusa ve Cermen Esir Kamplarındaki Tatarlar. $\mathrm{VI} / 21$ (1998) 65-80.

Kılıç, Selami: Ermeni Propagandaları ve Alman İmparatorluğu'nun Ermeni Politikası Alman Arşiv Belgeleri Açısından 1917-1918. V/19 (1997) 265-291.

Kılıç, Selami: Şapka Meselesi ve Kılık Kıyafet Inkılabı. IV/16 (1995) 529-547.

Kılıç, Selami: Türkiye'de Latin Harfleri Meselesi (1908-1928). II/7 (1991) 551-572.

Kısıkl1, Emine: Milli Mücadele Başlangıcında Mustafa Kemal Paşanın Milli Hareketi, Ittihat ve Terakki Faaliyetlerinden Uzak Tutma Teşebbüsleri. II/5 (1990) 109-127.

Kısıklı, Emıne: Sivas Kongresi'nin Milli Mücadelede Kamuoyu Oluşturulması Açısından Önemi. I/1 (1988) 29-42.

Kısıklı, Emine: Yeni Gelişmelerin Işı̆̆ında Geçmişten Günümüze Musul Meselesi. VI/24 (1999-2003) 487-526.

Kodamanoğlu, Nuri M: Laik Devlet Düzenimizin Illk Yasal Dayanağı. II/8(1991) 643-646.

Köni, Hasan: I'nci Dünya Savaşı Öncesinde Türk Dış Politikası. I/1 (1988) 43-63.

Köni, Hasan: 1921 Tarihli Türk-Fransız Anlașması Hakkında Bir Belge. I/2 (1988) 223-239.

Köni, Hasan: Genel Dış Politika Işı̆̆ında Cumhuriyet Dönemi Uzak-Doğu Illişkileri: 1933-1936. III/11 (1993) 271-277.

Köni, Hasan: Hatay Sorunu'na Yeni Bir Bakış. I/4 (1989) 535-539.

Köstüklü, Nuri: Milli Mücadele’de Keçiborlu. I/2 (1988) 257-280. 
Kurtcephe, İsrafil: Teşkilat-ı Mahsusa Belgelerine Göre 1917 Rus Ihtilali Sırasında Türkistan. III/12 (1993) 393-409.

Kurtcephe, İsrafil: Trablusgarb'ın Italyanlarca Işâli, Mustafa Kemal Ve Arkadaşlarının Direnişe Katılmaları. II/6 (1990) 361-375.

Mazıc1, Nurșen: 1930'a Kadar Basımın Durumu ve 1931 Matbuat Kanunu. V/18 (1996) 131-154.

Müderrisoğlu, Alptekin: Kurtuluş Savaşı'nm Mali Kaynaklart. IV/13 (1994) 27-53.

Müderrisoğlu, Alptekin: Vahdettin'in Kurtuluş Savaşın Başlatması İçin Mustafa Kemal Paşa'ya 400.000 Altın ve 400.000 Kağıt Lira Verdiği Gerçek Dışı Bir Iddiadır. IV/15 (1995) 291-303.

Oral, Mustafa: Ulusal Bağımsızlık Savaşı Yıllarında Türkiye'de Hilafet ve Saltanat Sorumu. V/18 (1996) 155-188.

Ozankaya, Özer: Ulusal Bayramların Toplumsal İşlevleri Açısından 30 Ağustos Zafer Bayrami. I/4 (1989) 541-547.

Ozankaya, Özer: Ulusal Toplumun ve Ulusal Kültürün Kurucu Ögeleri. III/10 (1992) 213-225.

Özçelik, Ayfer: Saltanatın Kaldırılmasından Sonra İstanbul'daki Durum (Felah Grubu Raporlarma Göre). III/9 (1992) 23-26.

Özdemir, Ahmet: Hukuk Dilinde Harp Esirleri. II/7 (1991) 573-577.

Özdemir, Ahmet: Milli Mücadelede Üsera Taburları. II/5 (1990) 129-150.

Özdemir, Ahmet: Savaş Esirlerinin Milli Mücadeledeki Yeri. II/6 (1990) 321-333.

Özdemir, Rifat: I. Dünya Savaşı Öncesi Osmanlı Batı Mücadelesi. I/2 (1988) 141163.

Özden, Neşe: The British Foreign Office Policies On Damad Ferid Paşa's Preparation For The Execution of The Treaty Of Sèvres (Sevr Barls Antlaşması'nın Yürürlüğe Girmesi İçin Damad Ferit Paşa'nın Hazırladığı Planlara Yönelik Ingiliz. Politikast). V/20 (1997) 423-455.

Özgiray, Ahmet: Atatürk ve Musiki. IV/15 (1995) 279-289.

Özgiray, Ahmet: Yunan Amaçlarn ve Itilaf Devletleriyle Birlikte Türkiye Üzerine Çevirdikleri Entrikalar (1914-1919). I/4 (1989) 549-561.

Özkaya, Yücel: Altı Illke. II/8(1991) 647-674.

Özkaya, Yücel: Gazi Mustafa Kemal Paşa'nın 1927 Istanbul ve Sonraki Gezileri. IV/14 (1994) 185-212.

Özkaya, Yücel: İzmir'in İşgalinin Anadolu'daki Tepkileri. I/1 (1988) 65-74.

Özkaya, Yücel: Türk Basınında Cumhuriyetin İlanınn Öncesi ve Sonrast. III/11 (1993) 279-310. 
Özkaya, Yücel: Ulusal Bağımsızlık Savaşında Anadolunun ve Kamu Oyunun Durumu. II/5 (1990) 151-165.

Özsarı, Mustafa: Ege Bölgesi Halkevleri ve Yayın Çalışmaları. VI/23 (1999) 401415.

Öztoprak, İzzet: Birinci İnönü Savaşı'nın Anadolu, İstanbul ve Dış Basında Karşılanı̧̧ ve Yorumu. VI/21 (1998) 81-96.

Öztürk, Cemil: Milli Mücadele Ankara'sında Bir Yaygın Yüksek Öğretim Kurumu: Serbest Âli Dersler Mïessese-i İlmiyyesi. IV/13 (1994) 55-63.

Pehlivanlı, Hamit: Askeri Polis Teşkilatı İstihbarat Raporlarında Milli Mücadele Sırasında Ermeni-Rum Azınlığın Faaliyetleri ve Alınan Tedbirler. II/8 (1991) 675-682.

Polat, İlknur: Atatürk ve Milli Eğitim. I/3 (1989) 437-445.

Polat, İlknur: Türk-Ittalyan İlişkileri Çerçevesinde İtalyan Okulları. I/4 (1989) 563575.

Sanal, Recep: Tarihi Gelişimi İçerisinde Türk Anayasalarında Genel Yönetimin Taşra Örgütüne İlişkin Düzenlemeler ve Yönetim Desenindeki Değişmeler. VI/22 (1998) 173-200.

Sarıkoyuncu, Ali: Milli Mücadele Döneminde Zonguldak Kömür Havzasında Fransız-Italyan Rekabeti ve Italya'nın Faaliyetleri. II/7 (1991) 579-590.

Sarıkoyuncu, Ali: Zonguldak ve Çevresinde Müdafaa-i Hukuk Çaışmaları. III/9 (1992) 27-51.

Sarıkoyuncu, Ali: Zonguldak ve Havalisinden Kuva-yı Milliye'ye Yapılan Yardımlar ve Temin Edilen Gelirler. III/10 (1992) 227-242.

Sarıkoyuncu, Ali: Zonguldak ve Havalisinin Milli Mücadele'de Ekonomik ve Stratejik Bakımdan Önemi. II/8 (1991) 683-693.

Sarığlu, Mehmet: Atatürk Devrimleriyle Ilgili Makaleler Bibliyografyası. IV/13 (1994) 65-75.

Sarısaman, Sadık: Birinci Dönem Türkiye Büyük Millet Meclisinde Kütahya Mebusu Besim Atalay Bey'in Faaliyetleri. IV/14 (1994) 213-242.

Sarısaman, Sadık: Cumhuriyetin Ilk Yıllarında Kadın Kıyafeti Meselesi. VI/21 (1998) 97-106.

Sarısaman, Sadık: Mustafa Kemal Paşa'nın Şebinkarahisar'ı Ziyareti. V/19 (1997) 293-302.

Sarısaman, Sadık: Ömer Naci Bey Miifrezesi. IV/16 (1995) 501-513.

Sarısaman, Sadık: Samsun ve Trabzon Mintıkası Ticaret Kongreleri (Ağustos-Eylül 1926). V/20 (1997) 457-464.

Savaş, Mevhibe: Mustafa Kemal, Amasya ve Iki Din Adamı. V/19 (1997) 315-323. 
Serin, Necdet: Atatürk'ün Íktisadi Politika Anlayışı I/2 (1988) 215-222.

Sezer, Hamiyet: Mustafa Kemal'in Anadolu'ya Gönderilmesi (Gotthard Jàschke [Jàeschke] Gözüyle). III/9 (1992) 53-74.

Shpuza, Gazmend: 1928-1930 Yıllarında Arnavut-Türk Illişkileri. V/19 (1997) 303313.

Shpuza, Gazmend: Atatürk ve Arnavutluk-Tïrkiye İlişkileri. II/6 (1990) 335-347.

Shpuza, Gazmend: Atatürk ve Arnavutluk-Türkiye İlişkileri. III/11 (1993) 311-322.

Shpuza, Gazmend: Doktor Temo'nun Atatürk Hakkındaki İmajı. IV/13 (1994) 7785.

Siler, Abdurrahman: Dış Borçlanma Karşısında Namık Kemal ve Atatürk. III/9 (1992) $75-84$.

Sonyel, Selahi R.: Mustafa Kemal Atatürk'ün Söylev'i. I/1 (1988) 75-81.

Söylemez, Faruk: Milli Mücadele Döneminde Kastamonu'da Kurulan Cemiyetler. IV/14 (1994) 243-254.

Söylemez, Faruk: Milli Mücadele'de Kastamonu Basım. III/12 (1993) 411-416.

Süer, Aydın: Ikbal Ali Şah ve Yeni Türkiyenin Yaratıcısı Kemal. IV/16 (1995) $455-$ 466.

Sürmeli, Serpil: Samsun ve Çevresinde Pontus Hareketi. V/19 (1997) 325-334.

Taşkıran, Cemalettin: Atatürk Döneminde Demokrasi Denemeleri (1925-1930). IV/14 (1994) 255-265.

Teodoseviç, Mariyana: 1924-1984 Yılları Arasında Yugoslavya'da Mustafa Kemal Atatürk Hakkında Çıkan Çalıșmaların Bibliyografik Eki. Çev.: Zeynep Zafer. V/18 (1996) 205-242.

Tosun, Hüseyin: Möntrö Boğazlar Sözleşmesi (Boğazlar Sorununda Son Aşama). IV/13 (1994) 87-112.

Turan, Mustafa: İstiklâl Harbinde "Müttefiklerarası Tahkik Heyeti" Çalışmaları, Rapor ve Tahkikat Neticesi. II/8 (1991) 695-722.

Turan, Mustafa: İmir'in İşâlinden Önce Anadolu'da Rum Taşkınlıkları ve Tedbirler. II/6 (1990) 349-360.

Turan, Şerafettin: Türkiye Cumhuriyeti: "Yeni Devlet" Temeli ve Nitelikleri. I/3 (1989) 447-462.

Türkman, Saim: Kuvayi Milliyenin Iaşe Ikmali ve Heyeti Temsiliyenin Kaynakları. VI/22 (1998) 201-210.

Türkmen. Zekeriya: Kurtuluş Savaşı Yıllarında Cephe Gerisine Gönderilen Gayr-i Müslim Vatandaşlarm Aileleriyle Haberleşmeleri. VI/22 (1998) 211-230. 
Ülker, Necmi: Çanakkale Zaferi'nin İzmir Basınındaki Akisleri. IV/14 (1994) 267 278.

Yaman, Ahmet Emin: Anadolu'daki Kongre Kararlartnda Silahl Direniş Güçlerinin Mali Finansman Ile Illgili Hükümler. I/1 (1988) 83-96.

Yaman, Ahmet Emin: Başkomutanlık Kanunu. III/9 (1992) 85-110.

Yaman, Ahmet Emin: Kurtuluş Savaşı Ekonomisi ve Maliyesi. III/12 (1993) 417 429.

Yaman, Ahmet Emin: Milli Ordu. I/2 (1988) 115-140.

Yaman, Ahmet Emin: Milli Ordudan Dïzenli Orduya. II/6 (1990) 377-401.

Yaman, Ahmet Emin: Mudanya Ateşkesi ve Yankulart. V/18 (1996) 189-203.

Yavuz, Bige: 1924 Türkiyesi'nde Devletin Siyasal Yaptsını Laikleştirme Çalıșmaları ve Karşı Tepkiler ile Illgili Bir Ingiliz Belgesi. III/11 (1993) 323-339.

Yavuz, Bige: Atatürk Devrimi ile Sosyal Yaşamın Çağdaşlaştırılmasına İlişkin Fransız Değerlendirilmeleri. IV/15 (1995) 305-342.

Yavuz, Bige Sükan: Fransız Arşiv Belgelerinin Işı̆̆ında Chester Demiryolu Projesi. VI/24 (1999-2003). 527-561.

Yavuz, Celalettin: Cemal Paşa'nın Almaya Gezisi-Bir Davetin Perde Arkası. V/19 (1997) 335-346.

Yavuz, Nurcan: Doğu Anadolu'daki Ermeni Mezaliminin Brest Litovsk Barış Görüşmelerinde Protestosu. IV/15 (1995) 381-406.

Yavuz, Nurcan: Rusya'nın Barış Dekretinin Kafkas Cephesi'ndeki Olaylara Etkisi. V/17 (1996) 83-87.

Yavuz, Ünsal: Mustafa Kemal'in Dumlupmar Söylevi (30. 8. 1924) Ile Illgili Bir Fransız Belgesi. III/9 (1992) 111-119.

Yazıcı, Nesimi: Hasan Basri (Çantay) ve Ses Gazetesi. II/12 (1993) 431-445.

Yel, Selma: Azerbaycan Cumhuriyeti Devleti'nin Kuruluşunda Türkiye'nin Yardımları Ilhak Amacına mı Yönelikti?. VI/24 (1999-2003) 563-578.

Yel, Selma: Mondros Mütarekesi ve Ingiliz Politikası. II/8 (1991) 723-731.

Yenişehirlioğlu, Şahin: Cumhuriyetin Kültürel Temeli. IV/16 (1995) 549-554.

Yılmaz, Veli: I'nci Dünya Harbi ve 2 Ağustos Tarihli Türk-Alman İttifak Antlașmast. III/9 (1992) 121-131.

Yolalıcı, M. Emin: Çă̆ımızda Milli Hakimiyet Anlayışları. IV/13 (1994) 113-119.

Yorulmaz, Şerife: Fransız Manda Yönetimi Döneminde Iskenderun Sancă̆ı (Hatay)'nın Sosyo-Ekonomik ve Siyasal Durumuna Iliş̧kin Bazı Kaynaklar (1918-1939). VI/22 (1998) 231-259. 
Yüceer, Saime: Vrangel Ordusu'nun İstanbul'daki Faaliyetleri. VI/21 (1998) 107117.

Yüksel, Ahmet Hâluk: Atatürkçü Düşünce Sistemine Dayall Toplumsal Kültür Anlayışı ve Kültürel Iletișim. I/4 (1989) 577-593.

Yüksel, Ahmet Halûk: Atatürkçü Düşünce Sisteminin Çağdaşlaşma Boyutunda Yönetsel ve Toplumsal İletişim. I/1 (1988) 97-114.

\section{MAKALE ADINA GÖRE}

11 Nisan 1920 (1336) Tarihli Takvim-i Vekâyi'de Kuva-y_ Milliye Aleyhinde Yaymlanan Kararlar. Osman Akandere. VI/24 (1999-2003) 417-467.

1919 Yılı Osmanlı İmparatorluğu'nda Osmanlılık Fikri Üzerine Değişik Görüşler. İclâl Karaca. II/7(1991) 539-550.

1920-1921 Yıllarında Rusya Hariciye Komiserliği İle Türkiye Büyük Millet Meclisi (T.B.M.M.) Arasında Kurulan İletişim. Mediha Akarslan. IV/16 (1995) 467-490.

1921 Tarihli Türk-Fransız Anlaşması Hakkında Bir Belge. Hasan Köni. I/2 (1988) 223-239.

1924 Türkiyesi'nde Devletin Siyasal Yapısını Laikleştirme Çaışmaları ve Karşı Tepkiler ile İlgili Bir İngiliz Belgesi. Bige Yavuz. III/11 (1993) 323-339.

1924-1984 Yılları Arasında Yugoslavya'da Mustafa Kemal Atatürk Hakkında Çıkan Çalışmalarm Bibliyografik Eki. Mariyana Teodoseviç. Çev.: Zeynep Zafer. V/18 (1996) 205-242.

1928-1930 Yıllarında Arnavut-Türk İlişkileri. Gazmend Shpuza. V/19 (1997) 303313.

1930 'a Kadar Basının Durumu ve 1931 Matbuat Kanunu. Nurşen Mazıcı. V/18 (1996) 131-154

Ali Rıza Paşa Hükûmeti Programı ve Meclis-i Mebusandaki Yankılar. İhsan Güneş. I/1 (1988) 13-27.

Altı İlke. Yücel Özkaya. II/8(1991) 647-674.

Amerikalı Misyonerlerin Ermeni Meselesindeki Rolü. Seçil Akgün. I/1 (1988) 1-12.

Anadolu Fevkalade Müfettiş-i Umumiliği - IV. Ve V. Damat Ferit Hükümetlerinin Anadolu'daki Yönetimi Büyük Millet Meclisi'nden Geri Alma Teşebbüsü (1920) -. Ali Arslan. IV/16 (1995) 443-453.

Anadolu'daki Kongre Kararlarında Silahlı Direniş Güçlerinin Mali Finansmanı Ile Ilgili Hükümler. Ahmet Emin Yaman. I/1 (1988) 83-96.

Ankara Hükümeti'nin Dïnya'ya Açılan Kapısı İnebolu-Ankara Yolu. Rahmi Çiçek. $\mathrm{V} / 20$ 399-413. 
Ankara Üniversitesi Türk Inkılap Tarihi Enstitüsü ve Enstitüde Hazırlanan Yüksek Lisans-Doktora Tezleri. Hacer Bayter. VI/23 (1999) 299-319.

Askeri Polis Teşkilatı İstihbarat Raporlarında Milli Mücadele Sırasında ErmeniRum Azınlığın Faaliyetleri ve Alınan Tedbirler. Hamit Pehlivanlı. II/8 (1991) 675-682.

Atatürk Çăgdaş Eğitimden Yana. Muzaffer Erendil. I/4 (1989) 523-534.

Atatürk Devrimi ile Sosyal Yaşamın Çağdaşlaştırılmasına Ilişkin Fransız Değerlendirilmeleri. Yavuz. Bige. IV/15 (1995) 305-342.

Atatürk Devrimleriyle Illgili Makaleler Bibliyografyası. Mehmet Sarığlu. IV/13 (1994) 65-75.

Atatürk Döneminde Demokrasi Denemeleri (1925-1930). Cemalettin Taşkuran. IV/14 (1994) 255-265.

Atatürk Döneminde Tarm Politikası. Vecdet Erkun. V/18 (1996) 243-248.

Atatürk Ilkelerinin Kişilik Boyutlart ve Eğitim Ortamı. İnal Cem Aşkun. I/4 (1989) 501-515.

Atatürk ve Anti-Emperyalizm. Mustafa Albayrak. V/20 (1997) 347-363.

Atatürk ve Arnavutluk-Türkiye İlişileri. Gazmend Shpuza. II/6 (1990) 335-347.

Atatürk ve Arnavutluk-Türkiye İlişkileri. Gazmend Shpuza. III/11 (1993) 311-322.

Atatürk ve Devrim'e Bakıs. Ergun Aybars. II/7 (1991) 443-453.

Atatürk ve Milli Eğitim. İlknur Polat. I/3 (1989) 437-445.

Atatürk ve Musiki. Ahmet Özgiray. IV/15 (1995) 279-289.

Atatïrk ve Sonrası Eğitim. Ziya Bursalığlu. I/4 (1989) 517-521.

Atatürk ve Yabancı Gözii Ile Bize Bıraktı̆̆ı Miras. Sema Çiğdemoğlu. IV/16 (1995) 515-527.

Atatürk. Medeniyet ve Dünya Капи Оуи. Muzaffer Erendil. II/5 (1990) 97-107.

Atatürk: Dünya Barışından Yana Bir Asker. Muzaffer Erendil. I/2 (1988) 165-179.

Atatürk'ün Bazı Kuruluşların Hatıra Defterlerine Yazdıkları. Hülya Baykal. I/2 (1988) 181-186.

Atatürk'ün Bulgar Basmmndaki Önemli Bir Polemik Hakkındaki Bilgi ve Görüşleri ve Ulusal Dış Politika Üzerine. Vahdet Keleşyılmaz. V/20 (1997) 415-422.

Atatürk'ün İktisadi Politika Anlayışı. Necdet Serin. I/2 (1988) 215-222.

Atatürkçü Dïşünce Sistemi ve Liberalizm. Mustafa Albayrak. V/18 (1996) 89-121.

Atatürkçü Düşünce Sistemine Dayalı Toplumsal Kültür Anlayıșı ve Kültürrel Illetişim. Ahmet Hâluk Yüksel. I/4 (1989) 577-593. 
Atatürkçü Düşünce Sisteminin Çağdaşlaşma Boyutunda Yönetsel ve Toplumsal Iletişim. Ahmet Halûk Yüksel. I/1 (1988) 97-114.

Atatiirkçülük ve Hoşgörü. İsmet Görgülü. V/17 (1996) 33-45.

Azerbaycan Cumhuriyeti Devleti'nin Kuruluşunda Türkiye'nin Yardımları Ilhak Amacma mı Yönelikti?. Selma Yel. VI/24 (1999-2003) 563-578.

Azmi Milli Yurdu Nizamnamesi. İhsan Güneş. III/12 (1993) 373-382.

Babam Enver Ziya Karal. Seçil Karal Akgün. VI/22 (1998) 165-171.

Başkomutanlık Kanumu. Ahmet Emin Yaman. III/9 (1992) 85-110.

Bir Harbiyelinin Milli Mücadele Antlarn. Mesut Çapa. IV/14 (1994) 141-166.

Bir Kuva-yı Milliye Gazetesine Göre Türk Barışı ve Ingiltere. Vahdet Keleşyılmaz. $\mathrm{V} / 19$ (1997) 249-264.

Bir Makale ve Dï̌şündürdükleri. Birten Çelik. V/17 (1996) 25-32.

Birinci Dönem Türkiye Büyïk Millet Meclisinde Kütahya Mebusu Besim Atalay Bey'in Faaliyetleri. Sadık Sarısaman. IV/14 (1994) 213-242.

Birinci İnönü Savaşı'nm Anadolu. İstanbul ve Dış Basında Karşılanışı ve Yorumu. İzzet Öztoprak. VI/21 (1998) 81-96.

Büyük Taarruz Günlerinde Ali Kemal ve Siyasi Göriüsleri. Bülent Çukurova. VI/23 (1999) 357-370.

Cemal Paşa'nun Almaya Gezisi-Bir Davetin Perde Arkası. Celalettin Yavuz. V/19 (1997) 335-346.

Cumhuriyet Dönemi Türk Edebiyatında Halk Evlerinin Rolü. Ö. Faruk Huyugüzel. $\mathrm{VI} / 23$ (1999) 391-400.

Cumhuriyetimizin Temeli: Atatiirkçü Düşünce. İnal Cem Aşkun. V/20 (1997) $387-$ 397.

Cumhuriyetin Ilk Yıllarında Gençliğin Savaşa Hazırlanması Ile Ilgili Iki Belge Iki Görüş. Mustafa Balcıoğlu. V/20 (1997) 465-473.

Cumhuriyetin Ilk Yıllarmda Hïkümetin Milli Ekonomi Oluşturma Girişimlerine Bir Örnek. Leyla Kaplan. VI/22 (1998) 159-164.

Cumhuriyetin Illk Yıllarında Kadın Kıyafeti Meselesi. Sadık Sarısaman. VI/21 (1998) 97-106.

Cumhuriyetin Kültiirel Temeli. Şahin Yenişehirlioğlu. IV/16 (1995) 549-554.

Cumhuriyetin Onuncu Yıldönümünde Atatürk'ün Kordiplomatiğe Bir Söylevi. Hülya Baykal. I/3 (1989) 395-397.

Çağımızda Milli Hakimiyet Anlayışlart. M. Emin Yolalıcı. IV/13 (1994) 113-119.

Çanakkale Zaferi ve Atatürk. İsmet Görgülü. IV/16 (1995) 491-500. 
Çanakkale Zaferi’nin Izmir Basınındaki Akisleri. Necmi Ülker. IV/14 (1994) $267-$ 278.

Çanakkale Zaferinin Türk ve Dïnya Tarihi Açısından Sonuçları. Rahmi Doğanay. III/12 (1993) 363-371.

Dahi Atatiirk. Cihat Akçakayalıŏglu. II/5 (1990) 167-176.

Dış Borçlanma Karşısında Namık Kemal ve Atatürk. Abdurrahman Siler. III/9 (1992) $75-84$.

Doğu Anadolu'daki Ermeni Mezaliminin Brest Litovsk Barıș Görüșmelerinde Protestosu. Nurcan Yavuz. IV/15 (1995) 381-406.

Doktor Temo'nun Atatürk Hakkmdaki Imajı. Gazmend Shpuza. IV/13 (1994) 77-85.

Ege Bölgesi Halkevleri ve Yaym Çalıșmaları. Mustafa Özsarı. VI/23 (1999) 401 415.

Elviye-i Selâse'nin Osmanlı Devleti'ne İadesi ve Bazı Uygulamalar. Mustafa Gül. IV/15 (1995) 367-380.

Ermeni Propagandalart ve Alman Imparatorluğu'nun Ermeni Politikası Alman Arşiv Belgeleri Açısından 1917-1918. Selami Kılıç. V/19 (1997) 265-291.

Erzurum Vilayet Kongresinde Alınan Kararlar ve Etkileri. Rahmi Çiçek. II/7 (1991) 513-537.

Evrensel Nitelikleriyle Atatürk. Muzaffer Erendil. II/6 (1990) 307-319.

Evrensel Nitelikleriyle Atatïrk. Muzaffer Erendil. III/9 (1992) 9-21.

Fransa'ntn Suriye'yi İşaline Dair Yaymlanmış Bir Risâle. Erdal İlter. V/17 (1996) 61-81.

Fransız Arşiv Belgelerinin Işı̆̆ında Chester Demiryolu Projesi. Bige Sükan Yavuz. VI/24 (1999-2003). 527-561.

Fransız Manda Yönetimi Döneminde İskenderun Sancă̆ı (Hatay)'nun SosyoEkonomik ve Siyasal Durumuna İlişkin Bazı Kaynaklar (1918-1939). Şerife Yorulmaz. VI/22 (1998) 231-259.

Gazi Mustafa Kemal Paşa'nun 1927 İstanbul ve Sonraki Gezileri. Yücel Özkaya. IV/14 (1994) 185-212.

Gazi Mustafa Kemal'in Samsun Öğretmenleri İle Konuşmast (22. IX. 1924). Sıtkı Aydınel. III/9 (1992) 1-8.

Genel Dış Politika Işı̆̆ında Cumluriyet Dönemi Uzak-Doğu Ilişkileri: 1933-1936. Hasan Köni. III/11 (1993) 271-277.

Halkevlerinin Kurulışu ve Tarihsel iş̧evi. Zeki Arıkan. VI/23 (1999) 261-281.

Hamza Grubu. Mesut Aydın. I/3 (1989) 371-394.

Hasan Basri (Çantay) ve Ses Gazetesi. Nesimi Yazıcı. II/12 (1993) 431-445. 
Hatay Sorunu'na Yeni Bir Bakıs. Hasan Köni. I/4 (1989) 535-539.

Hukuk Dilinde Harp Esirleri. Ahmet Özdemir. II/7 (1991) 573-577.

Hïsrev Bey Heyet-i Nasihası. Günay Çağlar. II/5 (1990) 85-96.

I. Dünya Savaşı Öncesi Osmanlı Batı Mücadelesi. Rifat Özdemir. I/2 (1988) 141163.

I'nci Dünya Harbi ve 2 Ağustos Tarihli Türk-Alman Ittifak Antlaşmast. Veli Yılmaz. III/9 (1992) 121-131.

II'nci Dünya Savaşı Öncesinde Türk Dış Politikası. Hasan Köni. I/1 (1988) 43-63.

Ikbal Ali Şah ve Yeni Türkiyenin Yaratıcısı Kemal. Aydın Süer. IV/16 (1995) 455 466.

İsmet Inönü'nün Lozan Döniişï ve Demeçleri (10 Ağustos 1923-23 Ağustos 1923). Cemal Avc1. III/12 (1993) 341-354.

Istikbal Gazetesine Göre Trabzon'da Mübadele ve İskân. Mesut Çapa. II/8 (1991) 631-641.

Istiklal Harbi Döneminde Batı Anadolu'da Yunan Zulmü. 1921. Mustafa Çufalı. VI/21 (1998) 33-48.

Istiklâl Harbimiz Üzerine Bazı Düşünceler. Cihat Akçakayalığlu. II/8 (1991) 627 629.

Istiklâl Harbinde "Müttefiklerarası Tahkik Heyeti" Çalışmaları. Rapor ve Tahkikat Neticesi. Mustafa Turan. II/8 (1991) 695-722.

İsgal Sırasında İzmirde Kurulan Bir Dernek. Zeki Arıkan. I/3 (1989) 355-369.

İmir'in İsgâlinden Önce Anadolu'da Rum Taşkınlıkları ve Tedbirler. Mustafa Turan. II/6 (1990) 349-360.

İzmir'in İsgalinin Anadolu'daki Tepkileri. Yücel Özkaya. I/1 (1988) 65-74.

Karizma ve Atatïrk'ün Önderliğindeki Gelişimi. İnal Zeki Akşun. I/2 (1988) 201213.

Köylii Gazetesi ve İsgal.Zeki Arıkan. L/2 (1988) 187-200.

Kurtuluş Savaşı Ekonomisi ve Maliyesi. Ahmet Emin Yaman. III/12 (1993) 417-429.

Kurtuluş Savaşı Yıllarında Cephe Gerisine Gönderilen Gayr-1 Müslim Vatandaşlarm Aileleriyle Haberleşmeleri. Zekeriya Türkmen. VI/22 (1998) 211230 .

Kurtuluş Savaşı'nda İstanbul ve Anadolu'daki Türk ve Düşman Gizli Faalivetleri. Necdet Ekinci. IV/14 (1994) 167-184.

Kurtuluş Savaşı'nda Türk-Fransız Ilişkileri ve Bir Fransız Tiurk Dostu Albay Mougin. Hülya Baykal. IU/7(1991) 455-511. 
Kurtuluş Savaşı'nın Mali Kaynakları. Alptekin Müderrisoğlu. IV/13 (1994) 27-53.

Kurtuluș Savaşında Yunan-Fener Patrikhanesi Birlikteliğine Karșt Örgütlü Bir Yaklaşım Türk Ortodoks Kilisesi. Esat Aslan. IV/15 (1995) 407-442.

Kurtuluş Savaşının Diplomatik Bir Cephesi- Inebolu. Rahmi Doğanay. VI/21 (1998) 49-64.

Kuvây-ı Inzibâtiye. Günay Çağlar. IV/15 (1995) 343-365.

Kuvayi Milliyenin İaşe Ikmali ve Heyeti Temsiliyenin Kaynakları. Saim Türkman. VI/22 (1998) 201-210.

Laik Devlet Dïzenimizin Illk Yasal Dayanağı. Nuri M Kodamanoğlu. II/8(1991) 643646.

Latin Harfler. Zeki Arıkan. II/5 (1990) 1-19.

Lozan'da Öngörülen Türk Ahâli Mübadelesinin Uygulanmasında Türkiye Kızılay (Hilâl-i Ahmer) Cemiyeti'nin Katkılarn. Mesut Çapa. I/2 (1988) 241-256.

Lozan'da Türkive Ile Amerika Birleşik Devletleri Arasında İmzalanan 6 Ağustos 1923 Tarihli Antlaşma. Erdal Açıkel. VI/21 (1998) 1-31.

Milli Kïltürümüzde Atatürkçülük ve Bugünümüz. Cihat Akçakayalığlu. I/3 (1989) 281-284.

Milli Mücadele Anıları Üzerine Bir Bibliyografya Denemesi. Bülent Çukurova. $\mathrm{VI} / 23$ (1999) 321-356.

Milli Mücadele Ankara'sında Bir Yaygın Yüksek Öğretim Kurumu: Serbest Âli Dersler Müessese-i İlmiyyesi. Cemil Öztürk. IV/13 (1994) 55-63.

Milli Mücadele Başlangıcında Mustafa Kemal Paşanm Milli Hareketi. Ittihat ve Terakki Faaliyetlerinden Uzak Tutma Teșebbüsleri. Emine Kısıklı. II/5 (1990) 109-127.

Milli Mücadele Döneminde Anadoluda Giriş ve Çıkışları Kontrol Altında Tutan Kuruluşlar. Mesut Aydın. II/5 (1990) 21-47.

Milli Mücadele Döneminde Balıkesir'de Kamuoyunun Oluşması ve Hey'et-i Merkeziye Karar Defteri Mediha Akarslan. V/17 (1996) 1-24.

Milli Mücadele Döneminde Istanbul'dan Anadolu'ya Geçen Subaylar. Mesut Aydın- Recep Dündar. II/6 (1990) 177-260.

Milli Mücadele Döneminde Ístikbal Gazetesi. Mesut Çapa. III/10 (1992) 133-168.

Milli Mücadele Döneminde Kastamonu'da Kurulan Cemiyetler. Faruk Söylemez. IV/14 (1994) 243-254.

Milli Mücadele Döneminde Türk-Ermeni ve Gürcii Ilişkileri. Cemal Avc1. IV/13 (1994) 1-10. 
Milli Müradele Döneminde Zonguldak Kömür Havzasında Fransı-Italyan Rekabeti ve Italya'mun Faaliyetleri. Ali Sarkoyuncu. II/7 (1991) 579-590.

Milli Mücadele Surasında Merkezi Anadolu'da Asayişi Sağlamak İçin Oluşturulan Milis Kuruluşları. Mustafa Balcıoğlu. II/6 (1990) 261-274.

Milli Mïcadele Yıllarında Anadolu'daki Yunan Savaş Esirlerini Ziyaret Eden Uluslararası Illk Kızılhaç Heyeti. Mesut Çapa. II/6 (1990) 281-294.

Milli Mïcadele'de “Doğu Lejyonu” (D'Orient)'nun Fransız $i_{\text {şgâl Bölgesindeki }}$ Fonksiyonu. Erdal İlter. I/3 (1989) 419-436.

Milli Mücadele'de Balıkesir. Zeki Arıkan. VI/24 (1999-2003) 469-474.

Milli Mücadele'de Kastamonu Basını. Faruk Söylemez. III/12 (1993) 411-416.

Milli Mïcadele'de Keçiborlu. Nuri Köstüklü. I/2 (1988) 257-280.

Milli Mücadele'de Manda Sorunu ve Mustafa Kemal'in Yaklaşım. Oğuz Aytepe. VI/24 (1999-2003) 475-586.

Milli Mücadelede Ermeni-Rum-Yunan Ittifakının Anadolu Basınındaki Yankıları. Rahmi Çiçek. II/6 (1990) 295-306.

Milli Mücadelede Üsera Taburlart. Ahmet Özdemir. II/5 (1990) 129-150.

Milli Ordu. Ahmet Emin Yaman. I/2 (1988) 115-140.

Milli Ordudan Düzenli Orduya. Ahmet Emin Yaman. II/6 (1990) 377-401.

Milli Teşkilatlar ve İstanbul Hükümetleri. Tülay Alim Baran. VI/23 (1999) 283-298.

Misak-ı Maarif. Seçil Akgün- Murat Uluğtekin. I/3(1989) 285-349.

Mondros Mütarekesi ve Ingiliz. Politikast. Selma Yel. II/8 (1991) 723-731.

Mondrostan Sonra Ermeni Meselesine Kısa Bir Bakış. İclâl Algıer. I/3(1989) 351354.

Möntrö Boğazlar Sözleşmesi (Boğazlar Sorununda Son Aşama). Hüseyin Tosun. IV/13 (1994) 87-112.

Mudanya Ateşkesi ve Yankıları. Ahmet Emin Yaman. V/18 (1996) 189-203.

Mustafa Kemal Paşa ve Milli Mücadele. Muhittin Birgen. V/20 (1997) 365-386.

Mustafa Kemal Atatürk’ün Söylev `i. Selahi R. Sonyel. I/1 (1988) 75-81.

Mustafa Kemal Paşa'nın Şebinkarahisar'ı Ziyareti. Sadık Sarısaman. V/19 (1997) 293-302.

Mustafa Kemal. Amasya ve Iki Din Adamı. Mevhibe Savaş. V/19 (1997) 315-323.

Mustafa Kemal'in Anadolu'ya Gönderilmesi (Gotthard Jàschke [Jàeschke] Gözüyle) Hamiyet Sezer. III/9 (1992) 53-74. 
Mustafa Kemal'in Dumlupunar Söylevi (30.8. 1924) Ile Ilgili Bir Fransız Belgesi. Ünsal Yavuz. III/9 (1992) 111-119.

Muvahhidin Cemiyeti. M. Metin Hülagü. III/12 (1993) 383-392.

Osmanl, Hükümetleri ve Tehcir Edilen Rum ve Ermenilerin Yeniden Iskan Meselesi. İbrahim Ethem Atanur. IV/14 (1994) 121-139.

Ömer Naci Bey Müfrezesi. Sadık Sarısaman. IV/16 (1995) 501-513.

Paris Barts Konferanst ve Sadri Maksudi'nin Türkive'yi Savunma Mücadelesine Bir Örnek. Musa Gürbüz. V/17 (1996) 47-60.

Rawlinson'un Gözüyle Mütareke Döneminde Doğu Anadolu ve Kafkasya. Rahmi Doğanay. VI/23 (1999) 371-390.

Rusya'nm Barış Dekretinin Kafkas Cephesi'ndeki Olaylara Etkisi. Nurcan Yavuz. V/17 (1996) 83-87.

Sakarya Savaşı Öncesi Karadeniz'de Yunan Ablukast ve İnebolu Bombardımanı. Rahmi Çiçek. III/10 (1992) 169-179.

Sakarya Savaşından Sonra Imzalanan Türk-Ingiliz. Esir Mübadelesi Anlașmasının Uygulanması ve Belgeler. Mesut Çapa. I/3 (1989) 399-418.

Saltanatın Kaldırılmasından Sonra İstanbul'daki Durum (Felah Grubu Raporlarna Göre). Ayfer Özçelik. III/9 (1992) 23-26.

Samsun ve Çevresinde Pontus Hareketi. Serpil Sürmeli. V/19 (1997) 325-334.

Samsun ve Trabzon Mıntıkası Ticaret Kongreleri (Ağustos-Eylïl 1926). Sadık Sarisaman. V/20 (1997) 457-464.

Savaş Esirlerinin Milli Mücadeledeki Yeri. Ahmet Özdemir. II/6 (1990) 321-333.

Savaș ve Bartş Üzerine. Bülent Daver. III/10 (1992) 181-186.

Sivas Kongresi Öncesinde "Manda ve Himayenin" Türk Basınında Tartışmasl ve Komutanlar Arasında Yazışmalar. Kadir Kasalak. III/10 (1992) 187-211.

Sivas Kongresi'nin Milli Mücadelede Kamuoyu Oluşturulması Açısından Önemi. Emine Kisıkl1. I/1 (1988) 29-42.

Söylev'deki Kişiliği İle Atatürk. İnal Cem Aşkun. III/1 1 (1993) 259-270.

Şapka Meselesi ve Kılık Kıyafet Inkılabı. Selami Kılıç. IV/16 (1995) 529-547.

Tarihi Gelişimi Içerisinde Türk Anayasalarında Genel Yönetimin Taşra Örgütüne Ilişkin Dï̈enlemeler ve Yönetim Desenindeki Değișmeler. Recep Sanal. VI/22 (1998) 173-200.

Teşkilat-ı Mahsusa Belgelerine Göre 1917 Rus İhtilali Strasında Türkistan. İsrafil Kurtcephe. III/12 (1993) 393-409.

Teşkilat-ı Mahsusa ve Cermen Esir Kamplarındaki Tatarlar. Vahdet Keleşyılmaz. VI/2I (1998) 65-80. 
“Teşvik-i Marifi Cemiyeti” İ̧̧ Tïzü̈̆̈ii. Zeki Arıkan. II/7 (1991) 403-421.

The British Foreign Office Policies On Damad Ferid Pașa's Preparation For The Execution of The Treaty Of Sèvres (Sevr Bartş Antlaşmast'nun Yürürlïğe Girmesi İ̧̧in Damad Ferit Pașa'nın Hazırladığı Planlara Yönelik Ingiliz Politikast). Neşe Özden. V/20 (1997) 423-455.

Trablusgarb'un Italyanlarca İsgâli. Mustafa Kemal Ve Arkadaşlarmm Direnişe Katılmaları. İsrafil Kurtcephe. II/6 (1990) 361-375.

Türk Baınında Cumhuriyetin Ilanının Öncesi ve Sonrası. Yücel Özkaya. III/11 (1993) 279-310.

Türk Kurtuluş Savaşı Dönemi Türkiye-İslam Ülkeleri Münasebetleri. M. Metin Hülagü. IV/13 (1994) 11-25.

Türk-İalyan Iliş̧kileri Çerçevesinde İalyan Okulları. İknur Polat. I/4 (1989) 563575.

Türkiye Cumhuriyeti: "Yeni Devlet" Temeli ve Nitelikleri. Şerafettin Turan. I/3 (1989) 447-462.

Türkiye'de Çok Partili Siyasi Hayatın Kurulmasında Bir Dönüm Noktast: 12 Temmuz (1947) Beyannamesi. Cezmi Eraslan. VI/22 (1998) 141-157.

Türkiye'de Ekonomik Kamu Düzcni Kavramma Bağlı Örgütsel Yönetimin Atatürkçü Dïsünce ve Kişilik Temelinde Konumuna Illişkin Bir Inceleme I. Inal Cem Aşkun. II/7 (1991) 423-442.

Türkiye'de Ekonomik Kamu Düzeni Kavramlarma Bağlı Örgütsel Yönetimin Atatürkçü Düşünce ve Kişilik Temelinde Konumuna Ilişkin Bir Inceleme II. İnal Cem Aşkun. II/8 (1991) 591-626.

Türkiye'de Latin Harfleri Meselesi (1908-1928). Selami Kılıç. II/7 (1991) 551-572.

Türkiye'nin Çăğdaşlaşmasında Tevfik Fikret ve Atatürk. Zeki Arıkan. VI/22 (1998) 119-140.

Ulusal Bă̆ımsızlık Savaşı Yıllarında Türkiye'de Hilafet ve Saltanat Sorunu. Mustafa Oral. V/18 (1996) 155-188.

Ulusal Bağımsızlık Savaşında Anadolunun ve Kamu Oyunun Durumu. Yücel Özkaya. II/5 (1990) 151-165.

Ulusal Bayramlarm Toplumsal İşlevleri Açısından 30 Ağustos Zafer Bayramı. Özer Ozankaya. I/4 (1989) 541-547.

Ulusal Toplumun ve Ulusal Kïltïrün Kurucu Ögeleri. Özer Ozankaya. III/10 (1992) 213-225.

Vahdettin'in Kurtuluş Savaşın Başlatması İ̧̧in Mustafa Kemal Paşa'ya 400.000 Altın ve 400.000 Kağıt Lira Verdiği Gerçek Dışı Bir Iddiadır. Alptekin Müderrisoğlu. IV/15 (1995) 291-303. 
Vrangel Ordusu'nun Istambul'daki Faaliyetleri. Saime Yüceer. VI/21 (1998) 107 117.

Wilson Ilkelerine Türk Kamuoyunun Tepkisi ve Bunun Amerikan Basınma Yanstması. Deniz Bilgen. V/18 (1996) 123-130.

XXIV. Tümen Komutanı Yarbay Mahmud Bey Olayı. Günay Çağlar. III/12 (1993) 355-361.

Yabancı Gözïyle Atatïrk. Ziya Bursalıŏlu. II/6 (1990) 275-280.

Yeni Gelişmelerin Işığında Geçmişten Günümüze Musul Meselesi. Emine Kısıklı. VI/24 (1999-2003) 487-526.

Yeni Gün Müsabakası'nda Mustafa Kemal Paşa. Zeki Arıkan. III/11 (1993) 243258.

Yeni Türk Harflerinin Kabulü Öncesinde Türk Kamuoyunda Bazı Tartışmalar ve Millet Mekteplerinin Açılması (1862-1928). Mustafa Albayrak. I/4 (1989) 463499.

Yunan Amaçlart ve İtilaf Devletleriyle Birlikte Türkiye Üzerine Çevirdikleri Entrikalar (1914-1919). Ahmet Özgiray. I/4 (1989) 549-561.

Yunanistan'dan Gelen Göçmenlerin İskânt. Mesut Çapa. II/5 (1990) 49-84.

Zonguldak ve Çevresinde Müdafaa-i Hukuk Çalışmaları. Ali Sarıkoyuncu. III/9 (1992) 27-51.

Zonguldak ve Havalisinden Kuva-yı Milliye'ye Yapılan Yardımlar ve Temin Edilen Gelirler. Ali Sarıkoyuncu. III/10 (1992) 227-242.

Zonguldak ve Havalisinin Milli Mücadele'de Ekonomik ve Stratejik Bakından Önemi. Ali Sarıkoyuncu. II/8 (1991) 683-693.

\section{KONULARA GÖRE}

\section{Amerika (Birleşik Devletleri)}

Açıkel, Erdal: Lozan'da Türkiye İle Amerika Birleşik Devletleri Arasında İmzalanan 6 Ağustos 1923 Tarihli Antlașma. VI/21 (1998) 1-31.

Akgün, Seçil: Amerikalt Misyonerlerin Ermeni Meselesindeki Rolii. I/1 (1988) 1-12.

Bilgen, Deniz: Wilson Ilkelerine Türk Kamuoyunun Tepkisi ve Bumun Amerikan Basına Yansıması. V/18 (1996) 123-130.

\section{Ankara Hükümeti}

Çiçek, Rahmi: Ankara Hükümeti'nin Dünya'ya Açılan Kapısı Inebolu-Ankara Yolu. V/20 399-413 


\section{Arnavut-Arnavutluk}

Shpuza, Gazmend: 1928-1930 Yıllarında Arnavut-Türk Ilişkileri. V/19 (1997) 303313.

Shpuza, Gazmend: Atatürk ve Arnavutluk-Tiirkiye İlişkileri. II/6 (1990) 335-347.

Shpuza, Gazmend: Atatürk ve Arnavutluk-Türkiye İlişkileri. III/I 1 (1993) 311-322.

\section{Arşiv Belgeleri}

Kılıç, Selami: Ermeni Propagandalarn ve Alman Imparatorluğu'nun Ermeni Politikası Alman Arşiv Belgeleri Açısından 1917-19/8. V/19 (1997) 265-291.

Yavuz, Bige Sükan: Fransız Arşiv Belgelerinin Işı̆̆ında Chester Demiryolu Projesi. VI/24 (1999-2003). 527-561.

\section{Atatürk (Gazi Mustafa Kemal Paşa)}

Akçakayalığlu, Cihat: Dahi Atatürk. II/5 (1990) 167-176.

Akşun, İnal Zeki: Karizma ve Atatürk'ün Önderliğindeki Gelişimi. I/2 (1988) 201213.

Arıkan, Zeki: Muhittin Birgen, Mustafa Kemal Paşa ve Milli Mücadele. V/20 (1997) 365-386.

Arıkan, Zeki: Türkiye'nin Çağdaşlaşmasında Tevfik Fikret ve Atatürk. VI/22 (1998) 119-140.

Arıkan, Zeki: Yeni Gün Müsabakası'nda Mustafa Kemal Paşa. III/11 (1993) 243258.

Aşkun, İnal Cem: Söylev'deki Kişiliği İle Atatürk. III/11 (1993) 259-270.

Aybars, Ergun: Atatürk ve Devrim'e Bakıs. II/7 (1991) 443-453.

Aydınel, Sıtkı: Gazi Mustafa Kemal'in Samsun Öğretmenleri Ile Konuşması (22. IX. 1924). III/9 (1992) 1-8.

Aytepe, Oğuz: Milli Mücadele'de Manda Sorunu ve Mustafa Kemal'in Yaklaşımı. VI/24 (1999-2003) 475-586.

Baykal, Hülya: Atatürk'ün Bazı Kuruluşlarm Hatıra Defterlerine Yazdıkları. I/2 (1988) 181-186.

Baykal, Hülya: Cumhurivetin Onuncu Yıldönümünde Atatïrk'ün Kordiplomatiğe Bir Söylevi. I/3 (1989) 395-397.

Bursalığlu, Ziya: Atatürk ve Sonrası Eğitim. I/4 (1989) 517-521.

Bursalığlu, Ziya: Yabancı Gözz̈̈yle Atatürk. II/6 (1990) 275-280. 
Çiğdemoğlu, Sema: Atatürk ve Yabancı Gözü Ile Bize Braktı̆̆ı Miras. IV/16 (1995) 515-527.

Daver, Bülent: Savaș ve Barı̧̧ Üzerine. III/10 (1992) 181-186.

Erendil, Muzaffer: Atatïrk Çağdaş Eğitimden Yana. I/4 (1989) 523-534.

Erendil, Muzaffer: Atatürk, Medeniyet ve Dünya Kaти Oуи. II/5 (1990) 97-107.

Erendil, Muzaffer: Atatürk: Dünya Barışından Yana Bir Asker. I/2 (1988) 165-179.

Erendil, Muzaffer: Evrensel Nitelikleriyle Atatürk. II/6 (1990) 307-319.

Erendil, Muzaffer: Evrensel Nitelikleriyle Atatürk. III/9 (1992) 9-21.

Erkun, Vecdet: Atatürk Döneminde Tarm Politikast. V/18 (1996) 243-248.

Görgülü, İsmet: Çanakkale Zaferi ve Atatürk. IV/16 (1995) 491-500.

Keleşyılmaz, Vahdet: Atatürk'ün Bulgar Basınındaki Önemli Bir Polemik Hakkındaki Bilgi ve Görüşleri ve Ulusal Dış Politika Üzerine. V/20 (1997) 415422 .

Kısıklı, Emine: Milli Mücadele Başlangıcında Mustafa Kemal Paşanın Milli Hareketi, Ittihat ve Terakki Faaliyetlerinden Uzak Tutma Teşebbüsleri. II/5 (1990) 109-127.

Kurtcephe, İsrafil: Trablusgarb'm İtalyanlarca İşâlli, Mustafa Kemal Ve Arkadaşlarmın Direnişe Katılmalart. II/6 (1990) 361-375.

Müderrisoğlu, Alptekin: Vahdettin'in Kurtuluş Savaşını Başlatması ļ̧̧in Mustafa Kemal Paşa'ya 400.000 Altın ve 400.000 Kağıt Lira Verdiği Gerçek Dışı Bir İdiadır. IV/15 (1995) 291-303.

Özgiray, Ahmet: Atatürk ve Musiki. IV/15 (1995) 279-289.

Özkaya, Yücel: Gazi Mustafa Kemal Paşa'nın 1927 İstanbul ve Sonraki Gezileri. IV/14 (1994) 185-212.

Polat, İlknur: Atatïrk ve Milli Eğitim. I/3 (1989) 437-445.

Sarığlu, Mehmet: Atatürk Devrimleriyle Ilgili Makaleler Bibliyografyassı. IV/13 (1994) 65-75.

Sarısaman, Sadık: Mustafa Kemal Paşa'nun Şebinkarahisar'ı Ziyareti. V/19 (1997) 293-302.

Savaş, Mevhibe: Mustafa Kemal, Amasya ve İki Din Adamı. V/19 (1997) 315-323.

Serin, Necdet: Atatürk'ün Íktisadi Politika Anlayışı I/2 (1988) 215-222.

Sezer, Hamiyet: Mustafa Kemal'in Anadolu'ya Gönderilmesi (Gotthard Jàshke [Jàeschke] Gözüyle). III/9 (1992) 53-74.

Shpuza, Gazmend: Atatïłk ve Arnavutluk-Türkiye Ilişkileri. II/6 (1990) 335-347.

Shpuza, Gazmend: Atatïrk ve Arnavutluk-Türkiye Illişkileri. III/11 (1993) 311-322. 
Shpuza, Gazmend: Doktor Temo'nun Atatïrk Hakkındaki Imaji. IV/13 (1994) 7785 .

Siler, Abdurrahman: Dış Borçlanma Karşısında Namık Kemal ve Atatürk. III/9 (1992) $75-84$.

Sonyel, Selahi R.: Mustafa Kemal Atatürk'ün Söylev'i. I/1 (1988) 75-81.

Süer, Aydın: Ikbal Ali Şah ve Yeni Türkiyenin Yaratıcısı Kemal. IV/16 (1995) 455 466.

Taşkıran, Cemalettin: Atatïrk Döneminde Demokrasi Denemeleri (1925-1930). IV/14 (1994) 255-265.

Teodoseviç, Mariyana: 1924-1984 Yıllart Arasında Yugoslavya'da Mustafa Kemal Atatürk Hakkında çıkan Çalışmalarm Bibliyografik Eki. Çev.: Zeynep Zafer. V/18 (1996) 205-242.

Yavuz, Bige: Atatürk Devrimi ile Sosyal Yaşamın Çağdaşlaştırılmasına İlişkin Fransız Değerlendirilmeleri. IV/15 (1995) 305-342.

Yavuz, Ünsal: Mustafa Kemal'in Dumluptnar Söylevi (30. 8. 1924) Ile Ilgili Bir Fransiz Belgesi. III/9 (1992) 111-119.

\section{Atatürk (Türk) Devrimi}

Arıkan, Zeki: Latin Harfler. II/5 (1990) 1-19.

Aybars, Ergun: Atatürk ve Devrim'e Bakış. II/7 (1991) 443-453.

Kılıç, Selami: Şapka Meselesi ve Kılık Kıyafet Inkılabı. IV/16 (1995) 529-547.

Kılıç, Selami: Tiurkiye'de Latin Harfleri Meselesi (1908-1928). II/7 (1991) 551-572.

Oral, Mustafa: Ulusal Bağınsızlık Savaşı Yıllarında Türkiye'de Hilafet ve Saltanat Sorunu. V/18 (1996) 155-188.

Sarıoğlu, Mehmet: Atatürk Devrimleriyle Ilgili Makaleler Bibliyografyası. IV/13 (1994) 65-75.

Yavuz, Bige: Atatürk Devrimi ile Sosyal Yaşamın Çağdaşlaştırılmasına Ilişkin Fransız Değerlendirilmeleri. IV/15 (1995) 305-342.

\section{Atatürk (Türk) Devrimi Sosyolojisi}

Ozankaya, Özer: Ulusal Bayramlarm Toplumsal İşlevleri Açısından 30 Ağustos Zafer Bayramı. I/4 (1989) 541-547.

Ozankaya, Özer: Ulusal Toplumun ve Ulusal Kültürün Kurucu Ögeleri. III/10 (1992) 213-225.

Yavuz, Bige: Atatürk Devrimi ile Sosyal Yaşamun Çağdaşlaştırılmasına İlişkin Fransız Değerlendirilmeleri. IV/15 (1995) 305-342.

Yenişehirlioğlu, Șahin: Cumhuriyetin Kültürel Temeli. IV/16 (1995) 549-554. 


\section{Atatürk İlkeleri}

Aşkun, İnal Cem: Atatïrk Ilkelerinin Kişilik Boyutları ve Eğitim Ortamı. I/4 (1989) 501-515.

Özkaya, Yücel: Altı Illke. II/8(1991) 647-674.

Yolalıcı, M. Emin: Çağımızda Milli Hakimiyet Anlayışları. IV/13 (1994) 113-119.

\section{Atatürkçü Düşünce}

Albayrak, Mustafa: Atatürkçü Dïşünce Sistemi ve Liberalizm. V/18 (1996) 89-121.

Aşkun, İnal Cem: Cumhuriyetimizin Temeli: Atatürkçü Düşünce. V/20 (1997) 387397.

Aşkun, İnal Cem: Türkiye'de Ekonomik Kamu Düzeni Kavramına Bağlı Örgütsel Yönetimin Atatürkçü Düşünce ve Kişilik Temelinde Konumuna İlişkin Bir Inceleme I. II/7 (1991) 423-442.

Aşkun, İnal Cem: Türkiye'de Ekonomik Kamu Düzeni Kavramlarma Bağlı Örgütsel Yönetimin Atatürkçü Diuşünce ve Kişilik Temelinde Konumuna İlişkin Bir Inceleme II. II/8 (1991) 591-626.

Yüksel, Ahmet Hâluk: Atatürkçü Dïşünce Sistemine Dayalı Toplumsal Kültür Anlayışı ve Kültürel Illetişim. I/4 (1989) 577-593.

Yüksel, Ahmet Halûk: Atatürkçü Düşünce Sisteminin Çăgdaşlaşma Boyutunda Yönetsel ve Toplumsal İletişim. I/1 (1988) 97-114.

\section{Atatürkçülük}

Akçakayalığlu, Cihat: Milli Kültüriumüzde Atatürkçülük ve Bugünümüz. I/3 (1989) 281-284.

Görgülü, İsmet: Atatürkçülük ve Hoşgörü. V/17 (1996) 33-45.

\section{Azmi Milli Yurdu}

Güneş, İhsan: Azmi Milli Yurdu Nizamnamesi. III/12 (1993) 373-382.

\section{Basın}

Arıkan, Zeki: Köylü Gazetesi ve Issgal. I/2 (1988) 187-200.

Bilgen, Deniz: Wilson Ilkelerine Türk Kamuoyunun Tepkisi ve Bunun Amerikan Bastmuna Yansıması. V/18 (1996) 123-130. 
Çapa, Mesut: Istikbal Gazetesine Göre Trabzon'da Mübadele ve İskân. II/8 (1991) 631-641.

Çapa, Mesut: Milli Mücadele Döneminde İstikbal Gazetesi. III/10 (1992) 133-168.

Çiçek, Rahmi: Milli Mïcadelede Ermeni-Rum-Yunan İttifakınm Anadolu Basınmdaki Yanklart. II/6 (1990) 295-306.

Kasalak, Kadir: Sivas Kongresi Öncesinde "Manda ve Himayenin" Türk Basınında Tartışması ve Komutanlar Arasında Yazışmalar. III/10 (1992) 187-211.

Keleşyılmaz, Vahdet: Atatürk'ün Bulgar Basınındaki Önemli Bir Polemik Hakkındaki Bilgi ve Görïşleri ve Ulusal Dış Politika Üzerine. V/20 (1997) 415422.

Keleşyılmaz, Vahdet: Bir Kuva-yt Milliye Gazetesine Göre Türk Bart=ı ve Ingiltere. V/19 (1997) 249-264.

Mazıc1, Nurşen: 1930'a Kadar Basının Durumu ve 1931 Matbuat Kanumu. V/18 (1996) 131-154.

Özkaya, Yücel: Türk Basınında Cumhuriyetin Ilanının Öncesi ve Sonrast. III/11 (1993) 279-310.

Öztoprak, İzzet: Birinci Inönü Savaşı'nın Anadolu, Istanbul ve Dış Basında Karşılanı̧ı ve Yorumu. VI/21 (1998) 81-96.

Söylemez, Faruk: Milli Miicadele'de Kastamonu Basını. III/12 (1993) 41 1-416.

Ülker, Necmi: Çanakkale Zaferi'nin İzmir Basınındaki Akisleri. IV/14 (1994) 267278.

Yazıcı, Nesimi: Hasan Basri (Çantay) ve Ses Gazetesi. II/12 (1993) 431-445.

\section{Başkomutanlık Kanunu}

Yaman, Ahmet Emin: Başkomutanlık Kanumu. III/9 (1992) 85-110.

\section{Bibliyografya Çalışmaları}

Çukurova, Bülent: Milli Mücadele Anları Üerine Bir Bibliyografva Denemesi. VI/23 (1999) 321-356.

Sarıoğlu, Mehmet: Atatürk Devrimleriyle İlgili Makaleler Bibliyografyası. IV/13 (1994) 65-75.

Teodoseviç, Mariyana: 1924-1984 Yılları Arasında Yugoslavya'da Mustafa Kemal Atatürk Hakkında Çıkan Çalışmalarm Bibliyografik Eki. Çev.: Zeynep Zafer. $\mathrm{V} / 18$ (1996) 205-242. 


\section{Birinci Dünya Savaşı}

Özdemir, Rifat: I. Dïnya Savaşı Öncesi Osmanlı Batı Mücadelesi. I/2 (1988) 141163.

Yılmaz, Veli: I'nci Dïnya Harbi ve 2 Ağustos Tarihli Türk-Alman Ittifak Antlaşmast. III/9 (1992) I21-131.

\section{Cemiyetler}

Arıkan, Zeki: Işgal Sirasında Izmirde Kurulan Bir Dernek. I/3 (1989) 355-369.

Arıkan, Zeki: "Teşvik-i Maarif Cemiyeti” İ̧ Tüzüğü. II/7 (1991) 403-421.

Çapa, Mesut: Lozan'da Öngörülen Türk Ahâli Mübadelesinin Uygulanmasında Türkiye Kı-ılay (Hilâl-i Ahmer) Cemiyeti'nin Katkıları. I/2 (1988) 241-256.

Hülagü, M. Metin: Muvahhidin Cemiyeti. III/12 (1993) 383-392.

Sarıkoyuncu, Ali: Zonguldak ve Çevresinde Müdafaa-i Hukuk Çalışmaları. III/9 (1992) 27-51 .

Söylemez, Faruk: Milli Mücadele Döneminde Kastamonu'da Kurulan Cemiyetler. IV/14 (1994) 243-254.

\section{Çanakkale Savaşları}

Çelik, Birten: Bir Makale ve Düşündürdükleri. V/17 (1996) 25-32.

Doğanay, Rahmi: Çanakkale Zaferinin Türk ve Dünya Tarihi Açısından Sonuçları. III/12 (1993) 363-371.

Görgülü, İsmet: Çanakkale Zaferi ve Atatürk. IV/16 (1995) 491-500.

Ülker, Necmi: Çanakkale Zaferi'nin İzmir Basınındaki Akisleri. IV/14 (1994) 267278.

\section{Dernekler}

Bk. Cemiyetler

\section{Dış Politik İlişkiler}

Avc1, Cemal: Milli Miicadele Döneminde Türk-Ermeni ve Gürcii Ilişkileri. IV/13 (1994) 1-10.

Baykal, Hülya: Kurtuluş Savaşı'nda Tïrk-Fransız Ilişkileri ve Bir Fransız Tïrk Dostu Albay Mougin. II/7(1991) 455-511. 
Hülagü, M. Metin: Türk Kurtuluş Savaşı Dönemi Türkiye-Islam Ülkeleri Mïnasebetleri. IV/13 (1994) 11-25.

Köni, Hasan: II'nci Dünya Savaşı Öncesinde Türk Dış Politikası. I/1 (1988) 4363.

Köni, Hasan: Genel Dış Politika Işı̆̆ında Cumhuriyet Dönemi Uzak-Doğu Ilişkileri: 1933-1936. III/11 (1993) 271-277.

Polat, İlknur: Türk-Italyan İlişkileri Çerçevesinde İtalyan Okulları. I/4 (1989) 563575.

Shpuza, Gazmend: 1928-1930 Yıllarinda Arnavut-Türk Ilişkileri. V/19 (1997) 303313.

Shpuza, Gazmend: Atatürk ve Arnavutluk-Türkive İlişkileri. II/6 (1990) 335-347.

Shpuza, Gazmend: Atatürk ve Arnavutluk-Türkiye İlişkileri. III/11 (1993) 311-322.

\section{Ekonomi Tarihi}

Aşkun, İnal Cem: Türkiye'de Ekonomik Kamu Düzeni Kavramına Băglt Örgütsel Yönetimin Atatürkçü Düşünce ve Kişilik Temelinde Konumuna İlişkin Bir inceleme I. II/7 (1991) 423-442.

Aşkun, Inal Cem: Türkiye'de Ekonomik Kamu Düzeni Kavramlarma Bağlı Örgütsel Yönetimin Atatürkçü Dïşünce ve Kişilik Temelinde Konumuna İlişkin Bir Inceleme II. II/8 (1991) 591-626.

Erkun, Vecdet: Atatürk Döneminde Tartm Politikası. V/18 (1996) 243-248.

Kaplan, Leyla: Cumhuriyetin Ilk Yıllarnda Hükümetin Milli Ekonomi Oluşturma Girişimlerine Bir Örnek. VI/22 (1998) 159-164.

Müderrisoğlu, Alptekin: Kurtuluş Savaşı'nın Mali Kaynakları. IV/13 (1994) 27-53.

Müderrisoğlu, Alptekin: Vahdettin'in Kurtuluş Savaşını Başlatması Için Mustafa Kemal Paşa'ya 400.000 Altın ve 400.000 Kağıt Lira Verdiği Gerçek Dışı Bir Iddiadr. IV/15 (1995) 291-303.

Sarkoyuncu, Ali: Zonguldak ve Havalisinin Milli Mücadele'de Ekonomik ve Stratejik Bakundan Önemi. 11/8 (1991) 683-693.

Serin, Necdet: Atatïrk'ün İktisadi Politika Anlayışı. I/2 (1988) 215-222.

Türkman, Saim: Kuvayi Milliyenin Iaşe Ikmali ve Heyeti Temsiliyenin Kaynakları. VI/22 (1998) 201-210.

Yaman, Ahmet Emin: Anadolu'daki Kongre Kararlarnnda Silahlı Direniş Güçlerinin Mali Finansman Ille Illgili Hükü̈mler. I/1 (1988) 83-96.

Yaman. Ahmet Emin: Kurtuluş Savaşı Ekonomisi ve Malivesi. III/12 (1993) 417 429. 
Yorulmaz. Şerife: Fransız. Manda Yönetimi Döneminde Iskenderun Sancağı (Hatay)'nın Sosyo-Ekonomik ve Sivasal Durumuna Ilişkin Bazı Kavnaklar (19/8-1939). VI/22 (1998) 231-259.

\section{Ermeni-Ermenistan}

Akgün, Seçil: Amerikalı Misyonerlerin Ermeni Meselesindeki Rolii. I/1 (1988) 1-12.

Algıer, İclâl: Mondrostan Sonra Ermeni Meselesine Kısa Bir Bakış. I/3(1989) 351354.

Atanur, İbrahim Ethem: Osmanlı Hükümetleri ve Tehcir Edilen Rum ve Ermenilerin Yeniden Iskan Meselesi. IV/14 (1994) 121-139.

Avcı, Cemal: Milli Mücadele Döneminde Türk-Ermeni ve Gürcü İlișkileri. IV/13 (1994) 1-10.

Çiçek, Rahmi: Milli Mücadelede Ermeni-Rum-Yunan Ittifakının Anadolu Basınundaki Yankilart. II/6 (1990) 295-306.

Kılıç, Selami: Ermeni Propagandaları ve Alman Imparatorluğu'nun Ermeni Politikası Alman Arşiv Belgeleri Açısından 1917-1918. V/19 (1997) 265-291.

Pehlivanlı, Hamit: Askeri Polis Teşkilatı Istihbarat Raporlarnda Milli Mücadele Sirasında Ermeni-Rum Azınlığın Faaliyetleri ve Alınan Tedbirler. II/8 (1991) 675-682.

Yavuz, Nurcan: Doğu Anadolu'daki Ermeni Mezaliminin Brest Litovsk Barıș Görüsmelerinde Protestosu. IV/15 (1995) 381-406.

\section{Fransa-Fransız}

Baykal, Hülya: Kurtuluş Savaşı'nda Türk-Fransız Ilişkileri ve Bir Fransız Türk Dostu Albay Mougin. II/7(1991) 455-511.

İlter, Erdal: Fransa'nın Suriye'yi İşgaline Dair Yayınlanmış Bir Risâle. V/17 (1996) $61-81$.

Ilter, Erdal: Milli Mücadele'de "Doğu Lejyonu" (D'Orient)'nun Fransız Isşâl Bölgesindeki Fonksiyonu. I/3 (1989) 419-436.

Köni, Hasan: 1921 Tarihli Türk-Fransız. Anlaşması Hakkında Bir Belge. I/2 (1988) 223-239.

Sarıkoyuncu, Ali: Milli Mïcadele Döneminde Zonguldak Kömïr Havzasında Fransiz-Italyan Rekabeti ve Italya'nun Faaliyetleri. II/7 (1991) 579-590.

Yavuz, Bige: Atatürk Devrimi ile Sosyal Yaşamın Çağdaşlaştırılmasına İlişkin Fransız Değerlendirilmeleri. IV/15 (1995) 305-342. 
Yavuz, Bige Sükan: Fransız Arşiv Belgelerinin Işığında Chester Demiryolu Projesi. VI/24 (1999-2003) 527-561.

Yavuz, Ünsal: Mustafa Kemal'in Dumlupınar Söylevi (30. 8. 1924) Ile Illgili Bir Fransiz Belgesi. III/9 (1992) 111-119.

Yorulmaz, Şerife: Fransız Manda Yönetimi Döneminde İskenderun Sancă̆ (Hatay)'nın Sosyo-Ekonomik ve Siyasal Durumuna İlişkin Bazı Kaynaklar (1918-1939). VI/22 (1998) 231-259.

\section{Gazeteler}

\section{Bk. Basın}

\section{Halkevleri}

Arıkan, Zeki: Halkevlerinin Kuruluşu ve Tarihsel Işlevi. VI/23 (1999) 261-281.

Huyugüzel, Ö. Faruk: Cumhuriyet Dönemi Türk Edebiyatında Halk Evlerinin Rolü. VI/23 (1999) 391-400.

Özsarı, Mustafa: Ege Bölgesi Halkevleri ve Yayın Çalışmaları. VI/23 (1999) 401415.

\section{Hamza Grubu}

Aydın, Mesut: Hamza Grubu. I/3 (1989) 371-394.

\section{Hatay Sorunu}

Köni, Hasan: Hatay Sorunu'na Yeni Bir Bakış. I/4 (1989) 535-539.

Yorulmaz, Şerife: Fransız Manda Yönetimi Döneminde İskenderun Sancă̆ı (Hatay)'nın Sosyo-Ekonomik ve Siyasal Durumuna Iliş̧in Bazı Kaynaklar (1918-1939). VI/22 (1998) 231-259.

\section{Heyet-i Nasiha}

Çağlar, Günay: Hüsrev Bey Heyet-i Nasihast. II/5 (1990) 85-96.

\section{Hilafet Sorunu}

Oral, Mustafa: Ulusal Bağımsızlık Savaşı Yıllarında Türkiye'de Hilafet ve Saltanat Sorunu. V/18 (1996) 155-188. 


\section{Hukuk Tarihi}

Özdemir, Ahmet: Hukuk Dilinde Harp Esirleri. II/7 (1991) 573-577.

\section{İngiliz-İngiltere}

Çapa, Mesut: Sakarya Savaşından Sonra Imzalanan Türk-Ingiliz Esir Mübadelesi Anlaşmasının Uygulanmast ve Belgeler. I/3 (1989) 399-418.

Keleşyılmaz, Vahdet: Bir Kuva-yı Milliye Gazetesine Göre Türk Barışı ve Ingiltere. $\mathrm{V} / 19$ (1997) 249-264

Özden, Neşe: The British Foreign Office Policies On Damad Ferid Pasa's Preparation For The Execution of The Treaty Of Sèvres (Sevr Barlş Antlaşması'nın Yürürlüğe Girmesi İçin Damad Ferit Paşa'nın Hazırladığı Planlara Yönelik Íngiliz Politikast). V/20 (1997) 423-455.

Yavuz, Bige: 1924 Türkiyesi'nde Devletin Siyasal Yapısını Laikleștirme Çalışmaları ve Karşı Tepkiler ile İlgili Bir Ingiliz Belgesi. III/11 (1993) 323-339.

Yel, Selma: Mondros Mütarekesi ve Ingiliz Politikas_. II/8 (1991) 723-731.

\section{İstanbul Hükümetleri}

Arslan, Ali: Anadolu Fevkalade Müfettiş-i Umumiliği - IV. Ve V. Damat Ferit Hükümetlerinin Anadolu'daki Yönetimi Büyük Millet Meclisi'nden Geri Alma Teşebbüsü (1920) -. IV/16 (1995) 443-453.

Atanur, İbrahim Ethem: Osmanlı Hükümetleri ve Tehcir Edilen Rum ve Ermenilerin Yeniden İskan Meselesi. IV/14 (1994) 121-139.

Baran, Tülay Alim: Milli Teşkilatlar ve İstanbul Hükümetleri. VI/23 (1999) 283298.

Güneş, İhsan: Ali Rıza Paşa Hükûmeti Programı ve Meclis-i Mebusandaki Yankılar. I/1 (1988) 13-27.

\section{İstiklâl Savaşı}

Bk. Kurtuluş Savaşı

\section{İsmet İnönü}

Avc1, Cemal: İsmet Ínönü'nün Lozan Dönüşü ve Demeçleri (10 Ağustos 1923-23 Ağustos 1923). III/12 (1993) 341-354. 


\section{İtalya-İtalyan}

Kurtcephe, İsrafil: Trablusgarb'in Italyanlarca İsgâli, Mustafa Kemal Ve Arkadaşlarının Direnişe Katılmaları. II/6 (1990) 361-375.

Polat, İlknur: Türk-Italyan İlişkileri Çerçevesinde Italyan Okulları. I/4 (1989) 563575.

Sarıkoyuncu, Ali: Milli Mücadele Döneminde Zonguldak Kömür Havzasında Fransız-Italyan Rekabeti ve Italya'nın Faaliyetleri. II/7 (1991) 579-590.

\section{İttihat ve Terakki}

Kısıklı, Emine: Milli Mücadele Başlangıcında Mustafa Kemal Paşanın Milli Hareketi, Ittihat ve Terakki Faaliyetlerinden Uzak Tutma Teşebbüsleri. II/5 (1990) 109-127.

\section{İzmir'in İşgali}

Arıkan, Zeki: İşgal Sirasında İzmirde Kurulan Bir Dernek. I/3 (1989) 355-369.

Arıkan, Zeki: Köylü Gazetesi ve İşgal. I/2 (1988) 187-200.

Özkaya, Yücel: İzmir'in İşgalinin Anadolu'daki Tepkileri. I/1 (1988) 65-74.

Turan, Mustafa: İzmir'in İsgâlinden Önce Anadolu'da Rum Taşkınlıkları ve Tedbirler. II/6 (1990) 349-360.

\section{Kamuoyu}

Akarslan, Mediha: Milli Mücadele Döneminde Balıkesir'de Kamuoyunun Oluşması ve Hey'et-i Merkeziye Karar Defteri. V/17 (1996) 1-24.

Albayrak, Mustafa: Yeni Türk Harflerinin Kabulü Öncesinde Türk Kamuoyunda Bazı Tartışmalar ve Millet Mekteplerinin Açılması (1862-1928). I/4 (1989) 463 499.

Bilgen, Deniz: Wilson Illkelerine Türk Kamuoyunun Tepkisi ve Bunun Amerikan Basınina Yansiması. V/18 (1996) 123-130.

Erendil, Muzaffer: Atatürk, Medeniyet ve Dünya Kamu Oyu. II/5 (1990) 97-107.

Kısıklı, Emine: Sivas Kongresi'nin Milli Mücadelede Kamuoyu Oluşturulması Açısından Önemi. I/1 (1988) 29-42.

Özkaya, Yücel: Ulusal Bağımsızlık Savaşında Anadolunun ve Kamu Oyunun Durumu. II/5 (1990) 151-165. 


\section{Kongreler}

Çiçek, Rahmi: Erzurum Vilayet Kongresinde Alınan Kararlar ve Etkileri. II/7 (1991) 513-537.

Kasalak, Kadir, Sivas Kongresi Öncesinde “Manda ve Himayenin” Türk Basınında Tartışması ve Komutanlar Arasında Yazışmalar. III/10 (1992) 187-211.

Kısıklı, Emine: Sivas Kongresi'nin Milli Mücadelede Kamuoyu Oluşturulmast Açısından Önemi. I/1 (1988) 29-42.

Sarısaman, Sadık: Samsun ve Trabzon Mintıkası Ticaret Kongreleri (A ğustos-Eylül 1926). V/20 (1997) 457-464.

Yaman, Ahmet Emin: Anadolu'daki Kongre Kararlarında Silahlı Direniş Güçlerinin Mali Finansmanı İle İlgili Hükümler. I/1 (1988) 83-96.

\section{Kurtuluş Savaşı}

Akarslan, Mediha: Milli Mücadele Döneminde Balıkesir'de Kamuoyunun Oluşması ve Hey'et-i Merkeziye Karar Defteri. V/17 (1996) 1-24.

Akçakayalığlu, Cihat: İstiklâl Harbimiz Üzerine Bazı Dï̧ünceler. II/8 (1991) 627 629.

Arıkan, Zeki: Milli Mücadele'de Balıkesir. VI/24 (1999-2003) 469-474.

Aslan, Esat: Kurtuluş Savaşında Yunan-Fener Patrikhanesi Birlikteliğine Kaşı Örgütlü Bir Yaklaşım Türk Ortodoks Kilisesi. IV/15 (1995) 407-442.

Avc1, Cemal: Milli Mücadele Döneminde Türk-Ermeni ve Gürcü İlişkileri. IV/13 (1994) 1-10.

Aydın, Mesut: Milli Mücadele Döneminde Anadoluda Giriş ve Çıkışları Kontrol Altında Tutan Kuruluşlar. II/5 (1990) 21-47.

Aydın, Mesut-Dündar, Recep: Milli Mücadele Döneminde İstanbul'dan Anadolu'ya Geçen Subaylar. II/6 (1990) 177-260.

Aytepe, Oğuz: Milli Mücadele'de Manda Sorunu ve Mustafa Kemal'in Yaklaşımı. VI/24 (1999-2003) 475-586.

Balcıoğlu, Mustafa: Milli Mücadele Sırasında Merkezi Anadolu'da Asayişi Sağlamak İ̧̧in Oluşturulan Milis Kuruluşları. II/6 (1990) 261-274.

Baykal, Hülya: Kurtuluş Savaşı'nda Türk-Fransız Illişkileri ve Bir Fransız Türk Dostu Albay Mougin. II/7(1991) 455-511.

Çapa, Mesut: Bir Harbiyelinin Milli Mücadele Anılart. IV/14 (1994) 141-166.

Çapa, Mesut: Milli Mücadele Döneminde İstikbal Gazetesi. III/10 (1992) 133-168.

Çapa, Mesut: Milli Mücadele Yıllarında Anadolu'daki Yunan Savaş Esirlerini Ziyaret Eden Uluslararası İlk Kızılhaç Heyeti. II/6 (1990) 281-294. 
Çiçek, Rahmi: Milli Mücadelede Ermeni-Rum-Yunan İtifakının Anadolu Basınındaki Yankılart. II/6 (1990) 295-306.

Çufalı, Mustafa: İstiklal Harbi Döneminde Batı Anadolu'da Yunan Zulmü, 1921. VI/21 (1998) 33-48.

Çukurova, Bülent: Milli Mücadele Anılart Üzerine Bir Bibliyografya Denemesi. $\mathrm{VI} / 23$ (1999) 321-356.

Doğanay, Rahmi: Kurtuluş Savaşının Diplomatik Bir Cephesi- Inebolu. VI/21 (1998) 49-64.

Ekinci, Necdet: Kurtuluş Savaşı'nda İstanbul ve Anadolu'daki Türk ve Düşman Gizli Faaliyetleri. IV/14 (1994) 167-184.

Hülagü, M. Metin: Türk Kurtuluş Savaşı Dönemi Türkiye-İslam Ülkeleri Münasebetleri. IV/13 (1994) 11-25.

İlter, Erdal: Milli Mücadele'de “Doğu Lejyonu” (D'Orient)'nun Fransız İşgâl Bölgesindeki Fonksiyonu. I/3 (1989) 419-436.

Kısıklı, Emine: Milli Mücadele Başlangıcında Mustafa Kemal Paşanın Milli Hareketi, Ittihat ve Terakki Faaliyetlerinden Uzak Tutma Teşebbüsleri. II/5 (1990) 109-127.

Kısıklı, Emine: Sivas Kongresi'nin Milli Mücadelede Kamuoyu Oluşturulması Açısından Önemi. I/1 (1988) 29-42.

Köstüklü, Nuri: Milli Mücadele’de Keçiborlu. I/2 (1988) 257-280.

Müderrisoğlu, Alptekin: Kurtuluş Savaşı'nın Mali Kaynakları. IV/13 (1994) 27-53.

Müderrisoğlu, Alptekin: Vahdettin'in Kurtuluş Savaşını Başlatması İçin Mustafa Kemal Paşa'ya 400.000 Altın ve 400.000 Kağıt Lira Verdiği Gerçek Dışı Bir Iddiadır. IV/15 (1995) 291-303.

Oral, Mustafa: Ulusal Bağımsızlık Savaşı Yıllarında Türkiye'de Hilafet ve Saltanat Sorunu. V/18 (1996) 155-188.

Özdemir, Ahmet: Milli Mücadelede Üsera Taburlart. II/5 (1990) 129-150.

Özdemir, Ahmet: Savaş Esirlerinin Milli Mücadeledeki Yeri. II/6 (1990) 321-333.

Öztürk, Cemil: Milli Mücadele Ankara'sında Bir Yaygın Yüksek Öğretim Kurumu: Serbest Âli Dersler Müessese-i İlmiyyesi. IV/13 (1994) 55-63.

Pehlivanlı, Hamit: Askeri Polis Teşkilatı Istihbarat Raporlarında Milli Mücadele Sırasında Ermeni-Rum Azınlığın Faaliyetleri ve Alman Tedbirler. II/8 (1991) 675-682.

Sarıkoyuncu, Ali: Milli Mücadele Döneminde Zonguldak Kömür Havzasında Fransız-Italyan Rekabeti ve Italya'nın Faaliyetleri. II/7 (1991) 579-590.

Sarıkoyuncu, Ali: Zonguldak ve Havalisinin Milli Mücadele'de Ekonomik ve Stratejik Bakımdan Önemi. II/8 (1991) 683-693. 
Söylemez, Faruk: Milli Mücadele Döneminde Kastamonu'da Kurulan Cemiyetler. IV/14 (1994) 243-254.

Söylemez, Faruk: Milli Mücadele’de Kastamonu Basını. III/12 (1993) 411-416.

Turan, Mustafa: Istiklâl Harbinde "Müttefiklerarası Tahkik Heyeti" Çalışmaları, Rapor ve Tahkikat Neticesi. II/8 (1991) 695-722.

Türkmen, Zekeriya: Kurtuluș Savaşı Yıllarında Cephe Gerisine Gönderilen Gayr-ı Müslim Vatandaşlartn Aileleriyle Haberleşmeleri. VI/22 (1998) 211-230.

Yaman, Ahmet Emin: Kurtuluş Savaşı Ekonomisi ve Maliyesi. III/12 (1993) $417-$ 429.

\section{Kuvâ-yı İnzibâtiye}

Çă̆lar, Günay: Kuvây-ı Inzibâtiye. IV/15 (1995) 343-365.

\section{Kuvâ-yı Milliye}

Akandere, Osman: II Nisan 1920 (1336) Tarihli Takvim-i Vekâyi'de Kuva-yt Milliye Aleyhinde Yaymlanan Kararlar. VI/24 (1999-2003) 417-467.

Keleşyılmaz, Vahdet: Bir Kuva-yı Milliye Gazetesine Göre Türk Barışı ve İngiltere. V/19 (1997) 249-264.

Sarıkoyuncu, Ali: Zonguldak ve Havalisinden Kuva-yı Milliye'ye Yapılan Yardımlar ve Temin Edilen Gelirler. III/10 (1992) 227-242.

Türkman, Saim: Kuvayi Milliyenin İase Ikmali ve Heyeti Temsiliyenin Kaynakları. VI/22 (1998) 201-210.

Yaman, Ahmet Emin: Milli Ordu. I/2 (1988) 115-140.

Yaman, Ahmet Emin: Milli Ordudan Düzenli Orduya. II/6 (1990) 377-401.

\section{Lozan Barıș Antlașması}

Açıkel, Erdal: Lozan'da Türkiye İle Amerika Birleşik Devletleri Arasında İmzalanan 6 Ağustos 1923 Tarihli Antlaşma. VI/21 (1998) 1-31.

Avcı, Cemal: Ísmet Inönü'nün Lozan Dönüşü ve Demę̧leri (10 Ağustos 1923-23 Ağustos 1923). III/12 (1993) 341-354.

Çapa, Mesut: Lozan'da Öngörülen Türk Ahâli Mübadelesinin Uygulanmasında Türkiye Kızılay (Hilâl-i Ahmer) Cemiyeti'nin Katkıları. I/2 (1988) 241-256.

\section{Milli Eğitim}

Akgün, Seçil-Uluğtekin, Murat: Misak-ı Maarif. I/3(1989) 285-349. 
Bursalıoğlu, Ziya: Atatürk ve Sonrast Eğitim. I/4 (1989) 517-521.

Erendil, Muzaffer: Atatürk Çağdaş Eğitimden Yana. I/4 (1989) 523-534.

Polat, Illknur: Atatürk ve Milli Eğitim. I/3 (1989) 437-445.

\section{Milli Mücadele}

\section{Bk. Kurtuluş Savașı}

\section{Mondros Ateşkes Antlaşması}

Algıer, İclâl: Mondrostan Sonra Ermeni Meselesine Kısa Bir Bakış. I/3(1989) 351354.

Yel, Selma: Mondros Mütarekesi ve İngiliz Politikast. II/8 (1991) 723-731.

\section{Montrö Boğazlar Sözleşmesi}

Tosun, Hüseyin: Möntrö Boğazlar Sözleşmesi (Bo_azlar Sorununda Son A_ama). IV/13 (1994) 87-112.

\section{Mudanya Ateşkes Antlaşması}

Yaman, Ahmet Emin: Mudanya Ateşkesi ve Yankıları. V/18 (1996) 189-203.

\section{Musul Sorunu}

Kısıklı, Emine: Yeni Gelişmelerin Işı ğında Geçmişten Günïmüze Musul Meselesi. VI/24 (1999-2003) 487-526.

\section{Osmanlı Devleti (İmparatorluğu)}

Atanur, İbrahim Ethem: Osmanlı Hükümetleri ve Tehcir Edilen Rum ve Ermenilerin Yeniden Iskan Meselesi. IV/14 (1994) 121-139.

Gül, Mustafa: Elviye-i Selâse'nin Osmanlı Devleti'ne Iadesi ve Bazı Uygulamalar. IV/15 (1995) 367-380.

Karaca, İclâl: 1919 Yılı Osmanlı İmparatorluğu'nda Osmanlılık Fikri Üzerine Değişik Görüşler. II/7(1991) 539-550.

Özdemir, Rifat: I. Dünya Savaşı Öncesi Osmanlı Batı Mücadelesi. I/2 (1988) 141 163. 


\section{Rum Azınlık}

Atanur, İbrahim Ethem: Osmanl Hükümetleri ve Tehcir Edilen Rum ve Ermenilerin Yeniden Ískan Meselesi. IV/14 (1994) 121-139.

Çiçek, Rahmi: Milli Mücadelede Ermeni-Rum-Yunan Ittifakının Anadolu Basınındaki Yankıları. II/6 (1990) 295-306.

Pehlivanlı, Hamit: Askeri Polis Teşkilatı İstihbarat Raporlarında Milli Mücadele Sırasında Ermeni-Rum Azınlığın Faaliyetleri ve Alınan Tedbirler. II/8 (1991) $675-682$.

Sürmeli, Serpil: Samsun ve Çevresinde Pontus Hareketi. V/19 (1997) 325-334.

Turan, Mustafa: İmir'in İşâlinden Önce Anadolu'da Rum Taşkınlıkları ve Tedbirler. II/6 (1990) 349-360.

\section{Rus-Rusya}

Akarslan, Mediha: 1920-192I Yıllarında Rusya Hariciye Komiserliği Ile Türkiye Büyük Millet Meclisi (T.B.M.M.) Arasında Kurulan İletişim. IV/16 (1995) $467-$ 490.

Kurtcephe, İsrafil: Teşkilat-ı Mahsusa Belgelerine Göre 1917 Rus Ihtilali Sirasında Türkistan. III/12 (1993) 393-409.

Yavuz, Nurcan: Rusya'nın Barıs Dekretinin Kafkas Cephesi'ndeki Olaylara Etkisi. V/17 (1996) 83-87.

Yüceer, Saime: Vrangel Ordusu'nun İstanbul'daki Faaliyetleri. VI/21 (1998) 107117.

\section{Sakarya Savaşı}

Çapa, Mesut: Sakarya Savaşından Sonra İmzalanan Türk-Ingiliz Esir Mübadelesi Anlaşmasının Uygulanması ve Belgeler. I/3 (1989) 399-418.

Çiçek, Rahmi: Sakarya Savaşı Öncesi Karadeniz'de Yunan Ablukası ve İnebolu Bombardımant. III/10 (1992) 169-179.

\section{Söylev (Nutuk)}

Aşkun, İnal Cem: Söylev'deki Kişiliği İle Atatürk. III/11 (1993) 259-270.

Sonyel, Selahi R.: Mustafa Kemal Atatürk'ün Söylev'i. I/1 (1988) 75-81.

\section{Tarihi Kişiler}

Alfred Rawlinson (Albay): Rahmi Doğanay: Rawlinson'un Gözüyle Mütareke Döneminde Doğu Anadolu ve Kafkasya. VI/23 (1999) 371-390. 
Ali Kemal: Bülent Çukurova: Büyük Taarruz Günlerinde Ali Kemal ve Siyasi Görïşleri. VI/23 (1999) 357-370.

Besim Atalay Bey: Sadık Sarısaman: Birinci Dönem Türkiye Büyük Millet Meclisinde Kütahya Mebusu Besim Atalay Bey'in Faaliyetleri. IV/14 (1994) 213-242.

Enver Ziya Karal: Seçil Karal Akgün: Babam Enver Ziya Karal. VI/22 (1998) 165-171.

Hasan Basri Çantay: Nesimi Yazıcı: Hasan Basri (Çantay) ve Ses Gazetesi. II/12 (1993) 431-445.

Hüsrev Bey: Günay Çağlar: Hüsrev Bey Heyet-i Nasihası. II/5 (1990) 85-96.

İbrahim Temo (Doktor): Gazmend Shpuza: Doktor Temo'nun Atatürk Hakkındaki İmajı. IV/13 (1994) 77-85.

İkbal Ali Şah: Aydın Süer: İkbal Ali Şah ve Yeni Türkiyenin Yaratıcısı Kemal. IV/16 (1995) 455-466.

Louis Mougin, (Albay): Hülya Baykal: Kurtuluş Savaşı'nda Türk-Fransız Iliş̧kileri ve Bir Fransiz Türk Dostu Albay Mougin. II/7(1991) 455-511.

Mahmud Bey (Yarbay): Günay Çağlar: XXIV. Tümen Komutant Yarbay Mahmud Bey Olayı. III/12 (1993) 355-361.

Ömer Naci Bey: Sadık Sarısaman: Ömer Naci Bey Müfrezesi. IV/16 (1995) 501513.

Sadri Maksudi: Musa Gürbüz: Paris Barış Konferansı ve Sadri Maksudi'nin Türkiye'yi Savunma Mücadelesine Bir Örnek. V/17 (1996) 47-60.

Tevfik Fikret: Zeki Arıkan: Türkiye'nin Çağdaşlaşmasında Tevfik Fikret ve Atatürk. VI/22 (1998) 119-140.

\section{Teşkilat-ı Mahsusa}

Keleşyılmaz, Vahdet: Teşkilat-ı Mahsusa ve Cermen Esir Kamplarındaki Tatarlar. VI/21 (1998) 65-80.

Kurtcephe, İsrafil: Teşkilat-ı Mahsusa Belgelerine Göre 1917 Rus Ihtilali Sırasında Türkistan. III/12 (1993) 393-409.

\section{Trablusgarb Savaşı}

Kurtcephe, İsrafil: Trablusgarb'ın İtalyanlarca İşgâli, Mustafa Kemal Ve Arkadaşlarının Direnişe Katılmaları. II/6 (1990) 361-375. 


\section{Türk İnkılap Tarihi Enstitüsü}

Bayter, Hacer: Ankara Üniversitesi Türk Inkılap Tarihi Enstitüsü ve Enstitüde Hazırlanan Yüksek Lisans-Doktora Tezleri. VI/23 (1999) 299-319.

\section{Türkiye Büyük Millet Meclisi}

Arslan, Ali: Anadolu Fevkalade Müfettiş-i Umumiliği - IV. Ve V. Damat Ferit Hükümetlerinin Anadolu'daki Yönetimi Büyük Millet Meclisi'nden Geri Alma Teşebbüsü (1920) -. IV/16 (1995) 443-453.

Akarslan, Mediha: 1920-1921 Yıllarında Rusya Hariciye Komiserliği İle Türkiye Büyük Millet Meclisi (T.B.M.M.) Arasında Kurulan İletişim. IV/16 (1995) 467490.

Sarısaman, Sadık: Birinci Dönem Türkiye Büyük Millet Meclisinde Kütahya Mebusu Besim Atalay Bey'in Faaliyetleri. IV/14 (1994) 213-242.

\section{Türkiye Cumhuriyeti}

Aşkun, İnal Cem: Cumhuriyetimizin Temeli: Atatürkçü Düşünce. V/20 (1997) $387-$ 397.

Balcıoğlu, Mustafa: Cumhuriyetin Ilk Yıllarında Gençliğin Savaşa Hazırlanması İle İlgili İki Belge Íki Görüş. V/20 (1997) 465-473.

Baykal, Hülya: Cumhuriyetin Onuncu Yıldönümünde Atatürk'ün Kordiplomatiğe Bir Söylevi. I/3 (1989) 395-397.

Huyugüzel, Ö. Faruk: Cumhuriyet Dönemi Türk Edebiyatında Halk Evlerinin Rolü. $\mathrm{VI} / 23$ (1999) 391-400.

Kaplan, Leyla: Cumhuriyetin Ilk Yıllarında Hükümetin Milli Ekonomi Oluşturma Girişimlerine Bir Örnek. VI/22 (1998) 159-164.

Kodamanoğlu, Nuri M: Laik Devlet Düzenimizin Illk Yasal Dayană̆ı. II/8(1991) 643-646.

Köni, Hasan: Genel Dış Politika Işı̆̆ında Cumhuriyet Dönemi Uzak-Doğu İlişkileri: 1933-1936. III/11 (1993) 271-277.

Özkaya, Yücel: Türk Basınında Cumhuriyetin Ilanının Öncesi ve Sonrası. III/11 (1993) 279-310.

Sanal, Recep: Tarihi Gelişimi İ̧erisinde Türk Anayasalarında Genel Yönetimin Taşra Örgütüne Ilişkin Düzenlemeler ve Yönetim Desenindeki Değişmeler. VI/22 (1998) 173-200.

Sarısaman, Sadık: Cumhuriyetin Ilk Yıllarında Kadın Kıyafeti Meselesi. VI/21 (1998) 97-106. 
Turan, Şerafettin: Türkiye Cumhuriyeti: "Yeni Devlet" Temeli ve Nitelikleri. I/3 (1989) 447-462.

Yenişehirlioğlu, Şahin: Cumhuriyetin Kültürel Temeli. IV/16 (1995) 549-554.

\section{Saltanat Sorunu}

Oral, Mustafa: Ulusal Bă̆ımsızlık Savaşı Yıllarında Türkiye'de Hilafet ve Saltanat Sorunu. V/18 (1996) 155-188.

Özçelik, Ayfer: Saltanatın Kaldırılmasından Sonra İstanbul'daki Durum (Felah Grubu Raporlarma Göre). III/9 (1992) 23-26.

\section{Ulusal Bağımsızlık Savaşı}

Bk. Kurtuluş Savaşı

\section{Yunan-Yunanistan}

Asłan, Esat: Kurtuluş Savaşında Yunan-Fener Patrikhanesi Birlikteliğine Karşı Örgütlü Bir Yaklaşım Türk Ortodoks Kilisesi. IV/15 (1995) 407-442.

Çapa, Mesut: Milli Mücadele Yıllarında Anadolu'daki Yunan Savaş Esirlerini Ziyaret Eden Uluslararası Illk Kızılhaç Heyeti. II/6 (1990) 281-294.

Çapa, Mesut: Yunanistan'dan Gelen Göçmenlerin İskânı. II/5 (1990) 49-84.

Çiçek, Rahmi: Milli Mücadelede Ermeni-Rum-Yunan Ittifakının Anadolu Basınındaki Yankıları. II/6 (1990) 295-306.

Çiçek, Rahmi: Sakarya Savaşı Öncesi Karadeniz'de Yunan Ablukası ve İnebolu Bombardımanı. III/10 (1992) 169-179.

Çufalı, Mustafa: İstiklal Harbi Döneminde Batı Anadolu'da Yunan Zulmü, 1921. VI/21 (1998) 33-48.

Özgiray, Ahmet: Yunan Amaçlart ve İtilaf Devletleriyle Birlikte Türkiye Üzerine Çevirdikleri Entrikalar (1914-1919). I/4 (1989) 549-561. 